\title{
Summer and fall habitat of North Atlantic right whales (Eubalaena glacialis) inferred from satellite telemetry
}

\author{
Mark F. Baumgartner and Bruce R. Mate
}

\begin{abstract}
Satellite-monitored radio tags were attached to North Atlantic right whales (Eubalaena glacialis) in Grand Manan Basin of the lower Bay of Fundy during the summer and early fall seasons of 1989-1991 and 2000. Monte Carlo tests were used to examine the distribution of the tagged whales in space and time and with respect to a variety of environmental variables to characterize right whale habitat on their northern feeding grounds. These environmental variables included depth, depth gradient, climatological surface and bottom hydrographic properties, and remotely sensed surface temperature, chlorophyll concentration, and their respective horizontal gradients. Site fidelity in the Bay of Fundy was very low during 1989-1991 and high during 2000. When the tagged animals left the Bay, they did not frequently visit the deep basins of the Gulf of Maine and Scotian Shelf, where abundances of their primary copepod prey, Calanus finmarchicus, are thought to be high. Instead, right whales visited areas characterized by low bottom water temperatures, high surface salinity, and high surface stratification. No evidence was found that the tagged right whales associated with oceanic fronts or regions with high standing stocks of phytoplankton.
\end{abstract}

Résumé : Des baleines franches noires (Eubalaena glacialis) ont été munies d'étiquette radio et surveillées par satellite dans le bassin de Grand Manan dans la baie de Fundy inférieure durant l'été et le début de l'automne en 1989-1991 et en 2000. Des épreuves de Monte Carlo ont servi à étudier la répartition des baleines marquées dans l'espace et le temps et en fonction d'une gamme de variables environnementales afin de caractériser l'habitat des baleines franches noires sur leurs aires d'alimentation du nord. Les variables environnementales comprenaient la profondeur, le gradient de profondeur, les propriétés hydrographiques de la surface et climatologiques du fond, les températures de surface déterminées par senseur à distance et la chlorophylle, ainsi que leurs gradients horizontaux respectifs. La fidélité au site était très faible dans la baie de Fundy en 1989-1991, mais élevée en 2000. Quand les animaux marqués quittaient la baie, ils ne visitaient pas souvent le golfe du Maine et la plate-forme néoécossaise, où il existe, estime-t-on, de fortes abondances de Calanus finmarchicus, le copépode qui leur sert de proie principale. Au contraire, les baleines franches noires visitaient des régions caractérisées par une température froide des eaux du fond, une salinité élevée en surface et une forte stratification de surface. Il n'y a pas d'indications qui laissent croire que les baleines franches noires marquéeassocient à des fronts océaniques ou des régions contenanimportants stocks de phytoplancton.

[Traduit par la Rédaction]

\section{Introduction}

The North Atlantic right whale (Eubalaena glacialis) is one of the most highly endangered whales (Clapham et al. 1999) and recent population assessments indicate that about 300 individuals remain (International Whaling Commission (IWC) 2001). Recovery of this population after centuries of

Received 24 February 2004. Accepted 31 August 2004.

Published on the NRC Research Press Web site at

http://cjfas.nrc.ca on 12 April 2005.

J18002

M.F. Baumgartner., ${ }^{1,2} 104$ Ocean Administration Building, College of Oceanic and Atmospheric Sciences, Oregon State University, Corvallis, OR 97331, USA.

B.R. Mate. Coastal Oregon Marine Experiment Station, Hatfield Marine Science Center, Oregon State University, Newport, OR 97365, USA.

${ }^{1}$ Corresponding author (e-mail: mbaumgartner@whoi.edu). ${ }^{2}$ Present address: Biology Department, MS \#33, Woods Hole Oceanographic Institution, Woods Hole, MA 02543, USA. whaling and subsequent international protection in the $1930 \mathrm{~s}$ has been slow or perhaps even nonexistent (IWC 2001). The hypothesized reasons for this lack of recovery have been numerous and include inbreeding, habitat degradation, competition for food, pollution, and human-caused mortality (IWC 2001). Knowlton and Kraus (2001) reported that 9 of the 19 known right whale mortalities during 1990-1999 were linked to ship strikes, and Kraus (1990) reported that 57\% of photographed right whales bear scars from fishing-gear entanglement. At current mortality rates, population models suggest that the North Atlantic right whale will become extinct in the next two centuries (Caswell et al. 1999). To help mitigate human-caused mortality, information about the distribution and habitat of right whales is desperately needed.

Traditional, large-scale habitat studies have combined shipboard or aerial surveys with oceanographic observations to elucidate associations between cetaceans and the environment (e.g., Cetacean and Turtle Assessment Program (CETAP) 1982; Reilly 1990; Baumgartner et al. 2001). These studies are limited in spatial and temporal coverage by the expense of operating a research vessel for long peri- 
ods of time. Radio tracking is a comparatively low-cost alternative that provides a unique, animal-based perspective that is only limited in spatial and temporal coverage by technological challenges such as attachment duration and battery life. To date, location data from satellite telemetry have been used largely in a descriptive fashion (e.g., where animals go, when they go there, and how long they stay) and have yet to be exploited profitably in a quantitative habitat study. These data, consisting only of dates and positions, seem simple, but statistical methods for exploring habitat associations with them are lacking. With the increasing availability of synoptic oceanographic information such as remotely sensed data, climatological data sets, and ocean model output, telemetry data can now be combined with a wealth of environmental data to investigate the habitat of marine animals.

We report here on a study of North Atlantic right whales equipped with satellite-monitored radio tags on their northern feeding grounds during the summer and early fall of 1989-1991 and 2000. We used Monte Carlo methods to examine the distribution of the tagged right whales in space and time and with respect to a variety of environmental variables. The environmental variables were chosen with specific hypotheses in mind. Right whales feed on older life stages of the copepod Calanus finmarchicus in every major high-use area of their feeding grounds in the northwestern Atlantic Ocean: Cape Cod Bay (Watkins and Shevill 1976; Mayo and Marx 1990), Great South Channel (Wishner et al. 1988, 1995; Beardsley et al. 1996), lower Bay of Fundy (Murison and Gaskin 1989; Woodley and Gaskin 1996; Baumgartner et al. 2003a), and Roseway Basin (Stone et al. 1988; Baumgartner et al. 2003a). Large concentrations of C. finmarchicus have been observed deep in the basins of the Scotian Shelf (Sameoto and Herman 1990), and modeling studies suggest that similarly large concentrations exist below $200 \mathrm{~m}$ in the deep Gulf of Maine basins (Lynch et al. 1998). We examined the hypothesis (denoted H1) that the tagged right whales use these basins to exploit the C. finmarchicus aggregations found there. Tidal mixing fronts are frequently observed in the study area (Ullman and Cornillon 1999) and we examined the hypothesis (H2) that the tagged right whales associate with these fronts because they provide improved feeding opportunities via the accumulation of biomass (Olson and Backus 1985; Epstein and Beardsley 2001). We also tested the hypothesis (H3) that the tagged right whales frequent areas with high surface chlorophyll concentrations because these conditions presumably provide feeding opportunities for their copepod prey.

Finally, we examined associations between the distribution of the tagged right whales and a variety of hydrographic properties. Baumgartner and Mate (2003) observed right whales foraging on discrete layers of $C$. finmarchicus stage5 copepodites (C5) just above the bottom mixed layer in the lower Bay of Fundy and Roseway Basin, so we investigated associations between the tagged whales and bottom water properties. During studies in the Great South Channel (Wishner et al. 1988, 1995; Brown and Winn 1989; Beardsley et al. 1996) and the lower Bay of Fundy (Murison and Gaskin 1989; Woodley and Gaskin 1996), right whales have frequently been observed in stratified waters (but see Baumgartner et al. 2003a), so we also examined associations between the distribution of the tagged whales and surface stratification.

\section{Materials and methods}

Each right whale was tagged with a satellite-monitored radio transmitter and tracked via the Argos system carried aboard the US National Oceanic and Atmospheric Administration (NOAA) Polar Orbiting Environmental Satellites (POES). The tag consisted of a Telonics ST-3 (1989), ST-6 (1990-1991), or ST-15 (2000) UHF radio transmitter housed in a surface-mounted (1989-1991) or an implantable (2000) stainless-steel cylinder. A salt-water switch and microprocessor were used to conserve battery power by limiting transmissions to times when the tag was out of the water and when the NOAA POES were likely overhead. Further details about the tag design and deployment methods can be found in Mate et al. (1997, 1998, 1999). Right whales were also photographed and individually identified when possible (after Kraus et al. 1986).

The environmental data for this study came from either static or temporally varying gridded data sets. We constructed a digital bathymetry from a variety of sources, including NOAA National Ocean Service sounding data, $2^{\prime}$ by $2^{\prime}$ data from satellite altimetry (Smith and Sandwell 1997), and ETOPO 5 gridded bathymetry (National Geophysical Data Center 1988). Depth gradient was computed from the digital bathymetry to examine associations between right whales and sea-floor topography. Horizontal gradients for depth, sea surface temperature (SST), and surface chlorophyll concentration (see below) were computed as vector quantities by using a 3 by 3 pixel Sobel gradient operator (a weighted average of finite differences; Russ 1995), and for brevity, the scalar gradient magnitude will be referred to as the gradient.

Remotely sensed SSTs with a nominal resolution of $1.1 \mathrm{~km}$ were acquired from the University of Rhode Island's advanced very high resolution radiometer archive (Cornillon et al. 1987). Reliable automated cloud masking was performed by the University of Rhode Island on the 1989-1991 data only, so we masked SST values in the 2000 data set that were judged extreme within a fixed temporal (10 days) and spatial $(36 \mathrm{~km}$ by $36 \mathrm{~km}$ ) window about a pixel. Owing to the crudeness of this approach in 2000, only 1989-1991 SST data are presented; however, the results of our analyses using SST data from all years were similar. Raw ocean color radiance data for 2000 were acquired from the sea-viewing wide field-of-view sensor and processed into gridded estimates of surface chlorophyll concentration with a nominal resolution of $1.1 \mathrm{~km}$ using SeaDAS software (version 4.0) (Baith et al. 2001). Both SST and surface chlorophyll concentration were coregistered to a digital coastline by hand with an accuracy of approximately \pm 1 pixel. Oceanic fronts can often be observed from remotely sensed data as regions of coherent horizontal variability in either SST or surface chlorophyll concentration, so both SST and surface chlorophyll gradient were computed as proxies for the presence of oceanic fronts. To investigate whether right whales visit areas historically rich in oceanic fronts, we also examined a climatology of 
monthly front-presence probabilities (Ullman and Cornillon 1999).

The hydrography of the Gulf of Maine and the Scotian Shelf is quite variable in space because of a variety of physical processes acting in a topographically complex region (Mountain and Jessen 1987). These processes include tidal mixing, slope water intrusions, wintertime convective and mechanical mixing, buoyancy forcing due to local and remote (e.g., St. Lawrence River) freshwater inputs, and stratification due to vernal warming. To examine associations between right whales and hydrographic features, a summertime climatology of surface temperature, salinity and stratification (density difference in the top $50 \mathrm{~m}$ of the water column), and bottom temperature and salinity was utilized (Loder et al. 1997).

Randomly generated simulated tracks were created from the observed Argos data for Monte Carlo tests (described below). For each tagged animal's track, 9999 corresponding simulated tracks were generated such that the initial location (tag-deployment site), the total distance traveled and the between-location distances and speeds for each simulated track were identical with those for the observed track, but the direction of travel between locations was randomly selected from a uniform distribution of angles between $0^{\circ}$ and $360^{\circ}$. The simulated locations were not allowed to occur on land, but straight-line paths between locations were allowed to cross small islands. The static environmental data were spatially averaged within a radius of $7.5 \mathrm{~km}$ around each observed and simulated location. All remotely sensed data were first temporally averaged within \pm 1 day of a locationacquisition time and then spatially averaged within a radius of $7.5 \mathrm{~km}$ around an observed or simulated location. Spatially averaged front probabilities were computed from the monthly climatology that corresponded to the locationacquisition time. If the location was beyond the domain of the gridded environmental data set or, in the case of the remotely sensed variables, more than $50 \%$ of the data in the spatial average were missing because of cloud contamination, the environmental datum for that location was flagged as a missing value. The spatial averaging radius was chosen as $7.5 \mathrm{~km}$ based on accuracy tests reported in Mate et al. (1997). They found that $68 \%$ of the poorest quality Argos locations (class 0) were within $7.5 \mathrm{~km}$ of the true transmitter location. Even if the location error is negligible, a right whale could potentially move up to $6 \mathrm{~km}$ at a maximum swimming speed of $18 \mathrm{~km} \cdot \mathrm{h}^{-1}$ during a NOAA POES overpass that can take up to $20 \mathrm{~min}$. Therefore, the $7.5-\mathrm{km}$ radius also accounts for any location uncertainty due to movement of the tagged whale during a satellite overpass.

Right whales generally remained in the lower Bay of Fundy in 2000 (see Results) and so a second simulation data set was created to minimize confounding due to selection of this habitat. The lower Bay of Fundy is a well-known habitat for right whales, so movements occurring outside the Bay are of particular interest. For each tagged animal's track outside the Bay of Fundy, 9999 corresponding simulated tracks were generated. The first location in each simulated track was the last acquired location in the Bay of Fundy before the animal exited the Bay. As before, the total distance traveled outside the Bay and the between-location distances and speeds for the simulated tracks were identical with those for the observed track. Only the direction of travel between locations was randomly selected. The simulated track ended if and when the tagged animal returned to the Bay of Fundy. Separate simulated tracks were generated each time a tagged animal left the Bay.

We used Monte Carlo tests to determine if the tagged right whales' observed distribution in space and time and with respect to each of the environmental variables could have occurred by chance (i.e., by simply moving at random). The null hypothesis in all of these tests is that the tagged right whales' distribution is random. Rejection of the null hypothesis in a two-tailed test provides evidence for either resource selection (preference) or resource rejection (avoidance) and the $p$ value from such a test is denoted $p_{2}$. The $p$ value from a one-tailed test for resource selection is denoted $p_{\mathrm{U}}$ and the $p$ value from a one-tailed tests for resource rejection is denoted $p_{\mathrm{L}}$.

The first Monte Carlo test was conducted to determine if the tagged right whales preferred or avoided particular regions or topographic features in the study area. To accomplish this, the total number of locations occurring over a particular feature was tallied for all of the tagged right whales. For each of the 9999 simulated track sets (a set consisted of one simulated track for each of the tagged whales), the total number of locations over the topographic feature was similarly tallied. The total number of locations occurring over the feature is regarded as a statistic of interest and the 10000 values for this statistic (9999 from the simulated track sets and 1 from the observed data) make up the sampling distribution of this statistic under the null hypothesis. Consider first a one-tailed test of resource selection. The null hypothesis is rejected if fewer than 5\% of the 10000 values in the sampling distribution are greater than or equal to the observed statistic. Rejection of the null hypothesis would suggest that the tagged right whales preferred the topographic feature in question, since more locations occurred there than expected. A one-tailed $p$ value $\left(p_{\mathrm{U}}\right)$ can be assigned to the observed statistic as the fraction of values in the sampling distribution that are greater than or equal to the observed statistic. Similarly, the $p$ value in a one-tailed test of resource rejection $\left(p_{\mathrm{L}}\right)$ can be assigned to the observed statistic as the fraction of values in the sampling distribution that are less than or equal to the observed statistic. A twotailed $p$ value for either resource selection or rejection $\left(p_{2}\right)$ is constructed as the smaller of $2 p_{\mathrm{U}}$ and $2 p_{\mathrm{L}}$ (Manly 1997).

In addition to the number of locations occurring over a particular topographic feature, the number of individuals was also tested in the same manner as described above. Because the Bay of Fundy is a well-known high-use area, selection of this habitat was examined over time with onetailed Monte Carlo tests of the numbers of locations and individuals occurring there in biweekly time intervals.

A two-dimensional frequency histogram was constructed to examine the null hypothesis of random spatial distribution. The study area was partitioned in $0.685^{\circ}$ longitude by $0.5^{\circ}$ latitude bins (nominally $56 \mathrm{~km}$ by $56 \mathrm{~km}$ ) and separate one-tailed Monte Carlo tests were conducted on the numbers of locations and individuals in each bin. Bins containing significant results represent areas that the tagged right whales 
Fig. 1. Map of the study area in eastern Canada and the USA, including location names. The 91-m (50 fathom) isobath is shown as a shaded line; basins are cross-hatched.

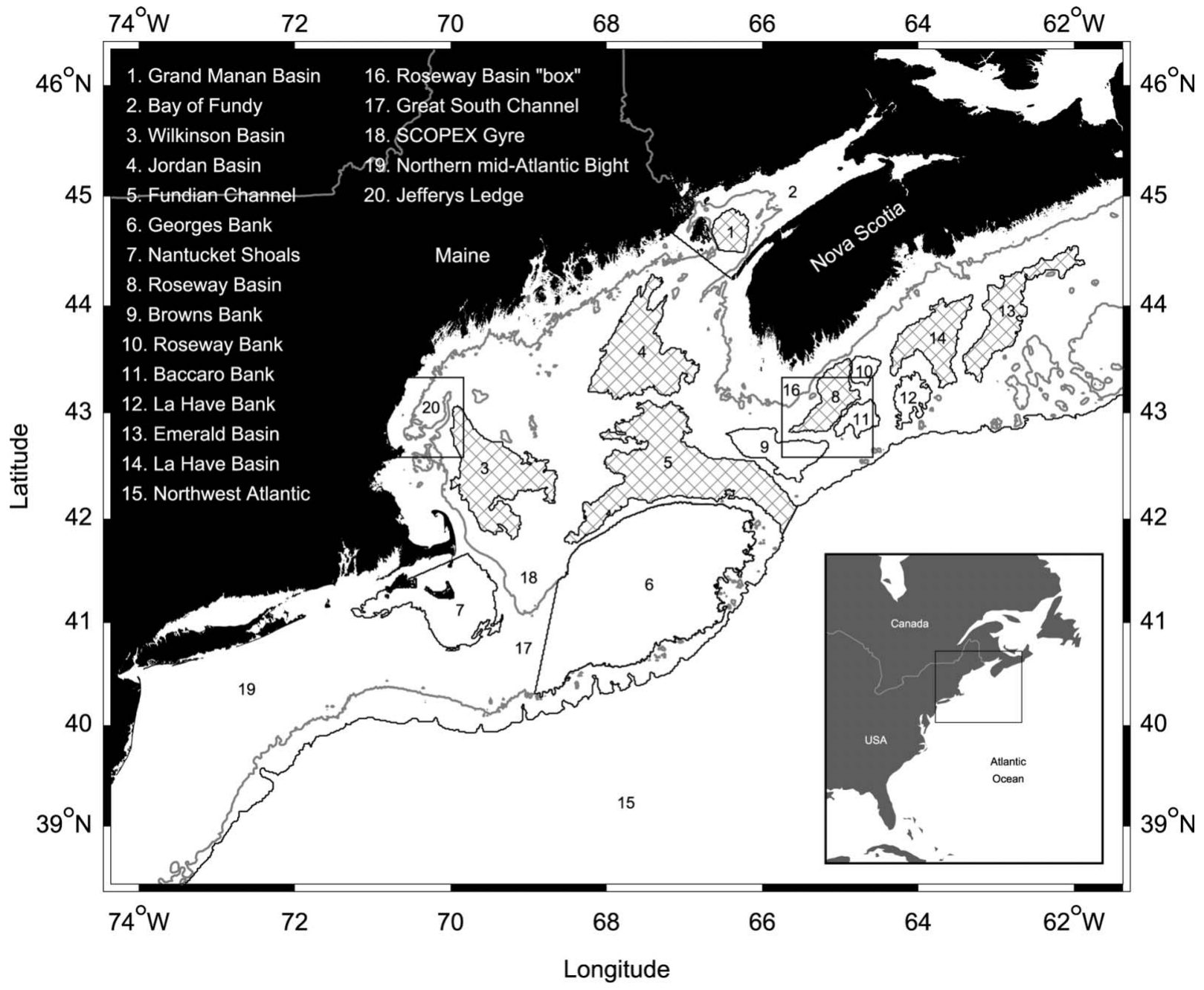

visited more than would be expected had they moved about at random.

Monte Carlo tests were also used to examine the null hypothesis that the tagged right whales were distributed randomly with respect to the environmental variables. Separate two-tailed Monte Carlo tests were conducted for the mean, standard deviation, skewness, and kurtosis of each environmental variable (Manly 1997). Significant results for any of these tests were interpreted as evidence that the tagged right whales' distribution was different from an expected distribution under the null hypothesis. To further examine the relationship between the tagged whales and the environmental variables, we constructed univariate frequency histograms for each variable and separate one-tailed Monte Carlo tests were conducted on the numbers of locations and individuals occurring in each histogram bin. Frequency histogram bin sizes were allowed to vary and were determined such that the average number of locations from the 10000 values in the sampling distribution for each bin was the same. Plots of collocated temperature and salinity measurements are useful for investigating water masses, so we constructed a bivariate frequency histogram for bottom salinity and bottom temperature to investigate the tagged right whales' distribution with respect to bottom water masses. The two-dimensional bin sizes were fixed at 0.25 practical salinity units (psu) and $1{ }^{\circ} \mathrm{C}$ for bottom salinity and bottom temperature, respectively. Separate one-tailed Monte Carlo tests were conducted on the numbers of locations and individuals in each bin.

For the univariate and bivariate one-tailed tests of resource selection, all bins with observed counts greater than zero were considered as well as those in which two or more locations occurring in a bin could be found significant (i.e., where $5 \%$ or more of the values in the sampling distribution exceeded zero). Resource rejection in a one-tailed test could only be detected when fewer than $5 \%$ of the values in the sampling distribution ( $2.5 \%$ for a two-tailed test) were zero. To illustrate this constraint, consider the most extreme case of potential resource rejection when zero observed locations or individuals occur in an area. Then only $5 \%$ or fewer of the values in the sampling distribution can be zero if statistical significance of the observed result in a one-tailed test is to be achieved (i.e., $p_{\mathrm{L}}<0.05$ ). In other words, an area must be potentially visited often, but actually visited infrequently (or never at all) to successfully detect resource rejection.

In the analyses described above, many Monte Carlo tests are carried out to determine the significance of an area or a 
Table 1. Summary data for each tag deployment, including the ID No. from the New England Aquarium (NEA) right whale catalog, tagging date, total number of locations, percentage of locations outside the Bay of Fundy (BOF), total (minimum) distance traveled (calculated as the sum of rhumb-line distances between Argos locations), and total duration of location acquisitions.

\begin{tabular}{|c|c|c|c|c|c|c|c|}
\hline $\begin{array}{l}\text { Tag ID } \\
\text { No. }\end{array}$ & $\begin{array}{l}\text { NEA } \\
\text { ID No. }\end{array}$ & Tagging date & $\begin{array}{l}\text { Total no. } \\
\text { of locations }\end{array}$ & $\begin{array}{l}\text { Locations } \\
\text { outside BOF }(\%)\end{array}$ & $\begin{array}{l}\text { Total distance } \\
\text { traveled }(\mathrm{km})\end{array}$ & $\begin{array}{l}\text { Total duration } \\
\text { (days) }\end{array}$ & $\begin{array}{l}\text { Label } \\
\text { (see Fig. 2) }\end{array}$ \\
\hline \multicolumn{8}{|l|}{1989} \\
\hline 843 & 1146 & 15 Oct. 1989 & 71 & 94.4 & 1511 & 21.2 & A \\
\hline \multicolumn{8}{|l|}{1990} \\
\hline 840 & 1135 & 24 Aug. 1990 & 15 & 66.7 & 770 & 6.4 & B \\
\hline 839 & 1140 & 24 Aug. 1990 & 108 & 88.0 & 3614 & 41.5 & $\mathrm{C}$ \\
\hline 823 & 1421 & 12 Sept. 1990 & 137 & 97.8 & 3104 & 42.1 & $\mathrm{~F}$ \\
\hline \multicolumn{8}{|l|}{1991} \\
\hline 1385 & 1243 & 27 Sept. 1991 & 6 & 83.3 & 218 & 7.9 & $\mathrm{G}$ \\
\hline 1386 & 1608 & 28 Sept. 1991 & 38 & 84.2 & 1787 & 23.7 & $\mathrm{H}$ \\
\hline 1387 & 1406 & 5 Oct. 1991 & 46 & 87.0 & 1321 & 21.4 & I \\
\hline \multicolumn{8}{|l|}{2000} \\
\hline $23039^{b}$ & 2320 & 11 Aug. 2000 & 114 & 53.5 & 6006 & 125.8 & $\mathrm{~L}$ \\
\hline 10829 & 2795 & 11 Aug. 2000 & 26 & 23.1 & 1547 & 66.0 & M \\
\hline 1387 & 2617 & 12 Aug. 2000 & 4 & 0.0 & 36 & 18.9 & $\mathrm{~N}$ \\
\hline 23040 & 1114 & 12 Aug. 2000 & 14 & 35.7 & 708 & 18.9 & $\mathrm{O}$ \\
\hline 824 & 1027 & 12 Aug. 2000 & 16 & 0.0 & 266 & 6.3 & $\mathrm{P}$ \\
\hline 823 & 2310 & 12 Aug. 2000 & 24 & 4.2 & 513 & 23.2 & Q \\
\hline 828 & 3030 & 12 Aug. 2000 & 39 & 61.5 & 2606 & 52.1 & $\mathrm{R}$ \\
\hline
\end{tabular}

Note: Location data are shown in Fig. 2.

${ }^{a}$ Whale not yet identified; hence missing NEA ID No.

${ }^{b}$ Nonmigrating portion: the total number of locations was $101,47.5 \%$ of locations were outside the BOF, the total distance traveled was $3718 \mathrm{~km}$, and total duration was 94.8 days.

single environmental variable. This multiple testing increases the likelihood of obtaining a significant result when, in fact, the null hypothesis is true (i.e., increases the probability of identifying resource selection when there is none). Since our study is exploratory, with the goal of identifying potential habitat, this Type I error is more acceptable than a Type II error (i.e., failing to identify resource selection when, in fact, it exists). Therefore, we chose not to use a multiple-testing adjustment to the selected significance level of 0.05 (e.g., Bonferroni adjustment), relying instead on coherent patterns in the results to judge ecological significance.

Right whale habitat is characterized here as an area or oceanographic regime that is visited by individual whales many times or for extended periods (i.e., the analyses of locations), or as an area/regime that is visited by many whales (i.e., the analyses of individuals). The Argos position data do not contain any explicit information about behavior, so it is impossible to determine if tagged whales are foraging, resting, or just traveling slowly through an area identified as habitat. However, high metabolic rates and a large body mass suggest that right whales must feed often to satisfy their energetic requirements (CETAP 1982; Kenney and Winn 1986; Kenney et al. 1986). Therefore, we assume that the primary motivation for resource selection is the presence of exploitable concentrations of right whale prey. We ac- knowledge that other factors may play a role in governing movements (e.g., reproduction) and these will be considered here as appropriate, but the movements of the tagged whales will be interpreted largely in the context of feeding and the physical and biological oceanographic processes that make prey available to right whales.

\section{Results}

Thirty-five right whales were equipped with satellitemonitored radio tags in Grand Manan Basin of the lower Bay of Fundy during the summer or early fall seasons of 1989-1991 and 2000 (Fig. 1). Eighteen whales were tracked for 6 days or more (Table 1) and locations for these animals were acquired, on average, 2.1 times $\cdot \mathrm{day}^{-1}$ for 20.5 days in 1989-1991 and 0.9 times $\cdot$ day $^{-1}$ for 43.2 days in 2000. These location-acquisition rates varied because programmed transmission rates were reduced in 2000 to conserve battery power. Only the 18 whales shown in Table 1 were used in the analyses. This sample size precluded an investigation of habitat differences among sex, age, and reproductive classes. One of the whales (23 039 in 2000, New England Aquarium ID No. 2320) migrated from the northern feeding grounds in mid-November to the only known wintering area off the Florida-Georgia coast in the USA. The migration portion of this whale's track was omitted from the analysis, since we 
Fig. 2. Argos-acquired locations for all tagged right whales (Eubalaena glacialis). Because of the large number of locations in the lower Bay of Fundy, locations there are indicated as solid circles. All locations for an individual animal outside the Bay of Fundy are denoted by the same letter. Summary data for each animal are included in Table 1. The 91-m (50 fathom) isobath and the features from Fig. 1 are shown.

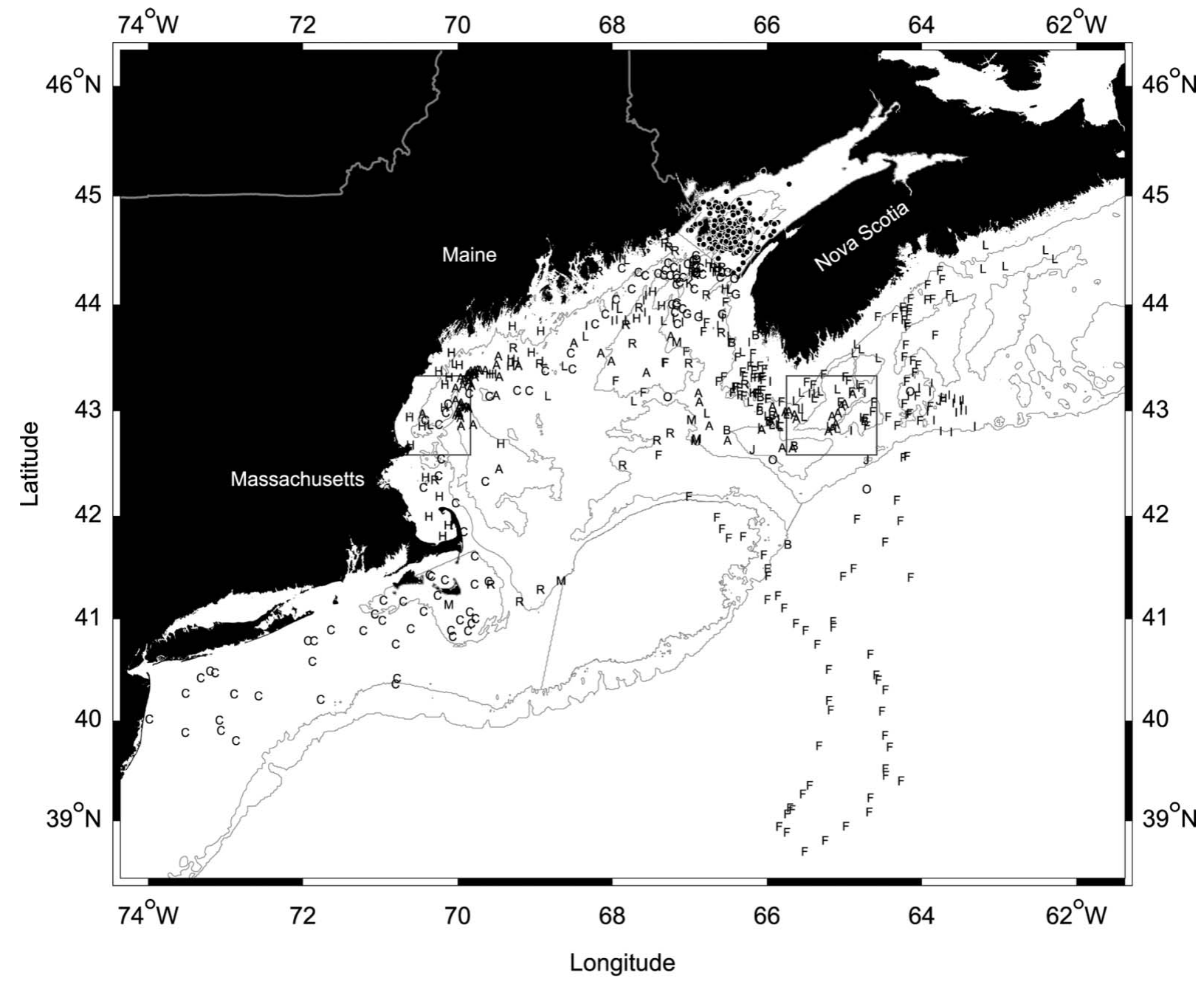

are concerned here only with habitat use on the northern feeding grounds. When the tagged right whales left the Bay of Fundy, they moved extensively throughout the Gulf of Maine, western Scotian Shelf, northern mid-Atlantic Bight, and on the continental slope at an average speed of $79 \mathrm{~km} \cdot \mathrm{day}^{-1}$ (Fig. 2).

During 1989-1991, only $16 \%$ of all acquired locations (71 of $454, p_{2}=0.060$ ) occurred in the lower Bay of Fundy (Table 2). In contrast, $70 \%$ of all locations (203 of 292, $p_{2}=$ 0.0008 ) acquired in 2000 occurred in the lower Bay of Fundy (Table 2). To examine whether these differences were an artifact of the tag-deployment times (late August through mid-October in 1989-1991 and early July through early August in 2000), we conducted one-tailed Monte Carlo tests on the biweekly occurrence of locations and individuals in the Bay of Fundy (Table 3). These tests demonstrate that from late August to mid October, significantly more locations and individuals occurred in the Bay of Fundy during 2000 than expected. During the same period in 1989-1991, the observed number of locations in the Bay of Fundy was consis- tently less than the mean of the sampling distribution. Because right whales exhibited such strong selection for the lower Bay of Fundy in 2000, the simulation data set for track segments outside the Bay was used for all subsequent analyses.

The number of locations in the deep basins of the Gulf of Maine and Scotian Shelf for all years was quite low (37; Table 3) and there was some suggestive but inconclusive evidence that the tagged whales that moved out of the Bay of Fundy actually avoided these deep basins $\left(p_{2}=0.093\right)$. The observed numbers of locations in the Fundian Channel (5) and Jordan Basin (19) were much lower than the mean of the sampling distribution (Table 4), though these results were not significant ( $p_{2}=0.065$ and $p_{2}=0.21$, respectively). More of the tagged right whales ( 7 individuals) visited the banks of the southwestern Scotian Shelf than expected $\left(p_{2}=\right.$ 0.0012 ), but only $4.5 \%$ of the locations outside the Bay of Fundy were found on these banks ( 22 of $491, p_{2}=0.073$ ). Interpretation of the tagged right whales' use of Roseway Basin depended on the definition of where this basin is actu- 
Table 2. Two-tailed Monte Carlo test results for the number $(n)$ of locations or individuals that occurred in the Bay of Fundy.

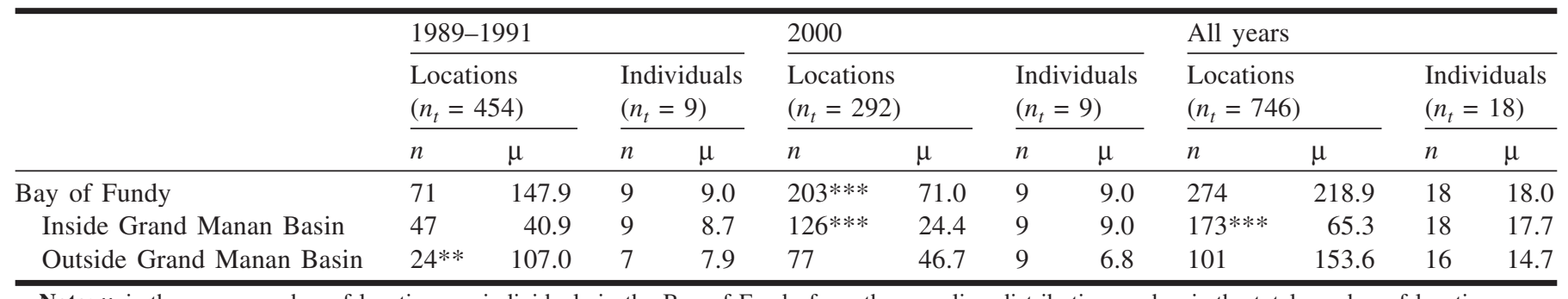

Note: $\mu$ is the mean number of locations or individuals in the Bay of Fundy from the sampling distribution, and $n_{t}$ is the total number of locations or individuals. **, $0.01>p \geq 0.001 ; * * *, p<0.001$.

Table 3. Results of one-tailed Monte Carlo tests of resource selection for the number $(n)$ of locations or individuals that occurred in the Bay of Fundy during 2-week intervals.

\begin{tabular}{|c|c|c|c|c|c|c|c|c|}
\hline & \multicolumn{4}{|c|}{ 1989-1991 } & \multicolumn{4}{|l|}{2000} \\
\hline & \multicolumn{2}{|c|}{ Locations } & \multicolumn{2}{|c|}{ Individuals } & \multicolumn{2}{|c|}{ Locations } & \multicolumn{2}{|c|}{ Individuals } \\
\hline & $n$ & $\mu$ & $n$ & $\mu$ & $n$ & $\mu$ & $n$ & $\mu$ \\
\hline 1-15 July & & & & & 6 & 5.3 & 2 & 2.0 \\
\hline 15-29 July & & & & & 2 & 0.5 & 1 & 0.2 \\
\hline 29 July - 12 Aug. & & & & & 11 & 3.1 & 3 & 2.2 \\
\hline 12-26 Aug. & 10 & 9.8 & 3 & 3.0 & $75^{*}$ & 40.4 & 7 & 6.3 \\
\hline 26 Aug. - 9 Sept. & 39 & 60.3 & 4 & 3.9 & $44 * *$ & 15.7 & $6 * *$ & 3.2 \\
\hline 9-23 Sept. & 3 & 25.1 & 1 & 1.7 & $33 * *$ & 3.8 & $3 * *$ & 0.8 \\
\hline 23 Sept. - 7 Oct. & 13 & 23.9 & 4 & 3.5 & $20 * *$ & 1.5 & $2 * *$ & 0.2 \\
\hline $7-21$ Oct. & 6 & 19.6 & 2 & 1.9 & $12 * * *$ & 0.5 & $2 * * *$ & 0.1 \\
\hline 21 Oct. - 4 Nov. & 0 & 8.9 & 0 & 0.7 & 0 & 0.1 & 0 & 0.0 \\
\hline 4-18 Nov. & 0 & 0.2 & 0 & 0.1 & 0 & 0.0 & 0 & 0.0 \\
\hline
\end{tabular}

Note: $\mu$ is the mean number of locations or individuals from the sampling distribution. *, $0.05>p \geq 0.01$;*, $0.01>$ $p \geq 0.001 ; * * *, p<0.001$.

ally located. No more locations or individuals were found in the basin area bounded by the 130-m isobath than expected (region 8 in Fig. 1); however, significantly more locations $\left(42, p_{2}=0.041\right)$ were found in the high-use area described by Mitchell et al. (1986) as Roseway Basin (region 16 in Fig. 1). More individuals (4) visited this area in 1989-1991 than expected $\left(p_{2}=0.040\right)$ and more locations (12) occurred here in 2000 than expected $\left(p_{2}=0.035\right)$. The locations acquired in 2000 were, however, from a single animal. The area around Jefferys Ledge, bounded to the south by $42^{\circ} 35^{\prime} \mathrm{N}$, to the north by $43^{\circ} 20^{\prime} \mathrm{N}$, to the east by $69^{\circ} 50^{\prime} \mathrm{W}$, and to the west by the coast (after Weinrich et al. 2000), had more locations $\left(32, p_{2}=0.044\right)$ and individuals $\left(3, p_{2}=\right.$ 0.024) than expected in 1989-1991, but there was no evidence that this area was frequented or avoided in 2000. Nantucket Shoals was visited by three individuals $\left(p_{2}=\right.$ $0.023)$ and more locations were acquired than expected (18, $p_{2}=0.025$ ); however, 16 of the 18 locations were from a single animal.

Significant concentrations of locations or individuals occurred in the western Gulf of Maine (north and west of Wilkinson Basin), on the southwestern Scotian Shelf, over Nantucket Shoals, in the northern mid-Atlantic Bight, and over the continental slope in the northwest Atlantic Ocean (Fig. 3). The latter three areas, however, were each predominantly occupied by only one animal (Fig. 2). The large number of locations between the mouth of the Bay of Fundy and Jordan Basin was not significantly higher than expected and appeared to be the result of the tagged animals using this region as a corridor when leaving from and returning to the Bay.

Monte Carlo tests of the mean, standard deviation, skewness, and kurtosis of the environmental variables suggest that the tagged right whales' distribution with respect to surface salinity, surface stratification, bottom temperature, bottom salinity, and SST gradient may differ from a random distribution (Table 5). The mean surface salinity $\left(p_{2}=\right.$ $0.0088)$ and bottom temperature $\left(p_{2}=0.016\right)$ were lower than expected, while the mean surface stratification $\left(p_{2}=\right.$ 0.023 ) was higher than expected. The kurtosis of bottom salinity, surface stratification, and SST gradient was different than expected $\left(p_{2}=0.024, p_{2}=0.024\right.$, and $p_{2}=0.032$, respectively). Although depth was not found to be significant for any of these statistics, the high mean depth (Table 5) suggests confounding by the few individuals that moved off the shelf into the very deep waters of the northwest Atlantic Ocean (Fig. 2; Table 4). When the 48 points occurring in this region were removed from the analysis, all of the observed statistics for depth became highly significant (mean: $\theta$ $=123.0, \mu=312.7, p_{2}=0.0032$; standard deviation: $\theta=$ 53.5, $\mu=658.0, p_{2}=0.0002$; skewness: $\theta=-0.03, \mu=5.49$, $p_{2}=0.0024$; kurtosis: $\theta=-0.58, \mu=40.48, p_{2}=0.0068$ ).

The patterns of significant results for either locations or individuals in the univariate frequency histograms (shown as probability density functions in Fig. 4) suggest that the tagged whales' distributions with respect to surface salinity, 
Table 4. Results of two-tailed Monte Carlo tests of the number $(n)$ of locations or individuals that occurred in regions outside the Bay of Fundy.

\begin{tabular}{|c|c|c|c|c|c|c|c|c|c|c|c|c|}
\hline & \multicolumn{4}{|c|}{ 1989-1991 } & \multicolumn{4}{|c|}{2000} & \multicolumn{4}{|c|}{ All years } \\
\hline & \multicolumn{2}{|c|}{$\begin{array}{l}\text { Locations } \\
\left(n_{t}=391\right) \\
\end{array}$} & \multicolumn{2}{|c|}{$\begin{array}{l}\text { Individuals } \\
\left(n_{t}=7\right)\end{array}$} & \multicolumn{2}{|c|}{$\begin{array}{l}\text { Locations } \\
\left(n_{t}=100\right) \\
\end{array}$} & \multicolumn{2}{|c|}{$\begin{array}{l}\text { Individuals } \\
\left(n_{t}=7\right) \\
\end{array}$} & \multicolumn{2}{|c|}{$\begin{array}{l}\text { Locations } \\
\left(n_{t}=491\right) \\
\end{array}$} & \multicolumn{2}{|c|}{$\begin{array}{l}\text { Individuals } \\
\left(n_{t}=14\right)\end{array}$} \\
\hline Deep basins & 26 & 56.1 & 5 & 5.4 & 11 & 15.6 & 3 & 3.7 & 37 & 71.6 & 8 & 9.1 \\
\hline Wilkinson Basin & 9 & 5.3 & 3 & 1.0 & 0 & $1.7^{a}$ & 0 & $0.9^{a}$ & 9 & 7.0 & 3 & 1.9 \\
\hline Jordan Basin & 13 & 30.3 & 4 & 4.7 & 6 & 7.4 & 2 & 2.8 & 19 & 37.8 & 6 & 7.5 \\
\hline Emerald Basin & 0 & $0.4^{a}$ & 0 & $0.1^{a}$ & 1 & 0.1 & 1 & 0.1 & 1 & 0.5 & 1 & 0.2 \\
\hline Scotian Shelf Banks & 18 & 5.3 & $4 *$ & 1.4 & 4 & 1.5 & $3 *$ & 0.8 & 22 & 6.8 & $7 * *$ & 2.2 \\
\hline Browns Bank & 4 & 3.8 & 2 & 1.1 & 2 & 1.1 & 2 & 0.6 & 6 & 4.9 & 4 & 1.8 \\
\hline Roseway Bank & 0 & $0.3^{a}$ & 0 & $0.2^{a}$ & 1 & 0.1 & 1 & 0.1 & 1 & 0.4 & 1 & 0.2 \\
\hline Baccaro Bank & 6 & 0.7 & $3 * *$ & 0.3 & 0 & $0.2^{a}$ & 0 & $0.1^{a}$ & 6 & 0.9 & $3 *$ & 0.4 \\
\hline Georges Bank & 4 & $13.1^{a}$ & 1 & $1.6^{a}$ & 0 & $4.7^{a}$ & 0 & $1.7^{a}$ & 4 & 17.9 & 1 & 3.3 \\
\hline Nantucket Shoals & $16^{*}$ & 1.0 & 1 & 0.2 & 2 & 0.5 & 2 & 0.3 & $18 *$ & 1.5 & $3 *$ & 0.6 \\
\hline Northwest Atlantic Ocean & 47 & 20.2 & 3 & 1.9 & 1 & $10.5^{a}$ & 1 & $1.9^{a}$ & 48 & 30.7 & 4 & 3.8 \\
\hline
\end{tabular}

Note: Results were obtained using observed and simulated track segments outside of the Bay of Fundy. $\mu$ is the mean number of locations or individuals in these regions from the sampling distribution, and $n_{t}$ is the total number of locations or individuals. $*, 0.05>p \geq 0.01 ; * *, 0.01>p \geq 0.001$.

${ }^{a} p_{\mathrm{L}}$ (see Materials and methods) could not be assessed because more than $2.5 \%$ of the values in the sampling distribution were zero.

${ }^{b}$ Includes Georges Basin and the Northeast Channel.

${ }^{c}$ Area enclosed by the $130-\mathrm{m}$ isobath (region 8 of Fig. 1).

${ }^{d}$ High-use area observed in Blanford whaling records (Mitchell et al. 1986) (region 16 of Fig. 1).

surface stratification, bottom temperature, bottom salinity, and depth were indeed different than expected. The number of locations or individuals outside the Bay of Fundy was significantly greater than expected in waters of low surface salinity (Fig. $4 c$ ) and high surface stratification (Fig. 4g). The lowest two frequency histogram bins for surface salinity contained 29\% of all locations (142 of 491), whereas the highest two bins for surface stratification contained $27 \%$ of all locations (134 of 491). Since surface salinity and surface stratification are correlated in the data, it is not surprising that the same subset of locations contributed to the significance of both of these variables. Significantly more locations or individuals were found in waters with low bottom temperatures (Fig. $4 f$ ) and the lowest two frequency histogram bins for this variable contained $25 \%$ of all locations (125 of 491). The pattern of significant results for bottom salinity is less coherent (Fig. 4e); however, it is worth noting that $37 \%$ of locations found inside the Bay of Fundy (102 of 274) fell within the range 33.21-33.39 psu (bins 2 and 3 in Fig. 4e). The number of locations or individuals in waters of 133-165 m depth (bins 2-4 in Fig. $4 a$ ) was also significantly greater than expected and $24 \%$ of locations inside the Bay of Fundy (66 of 274) were found in this depth range. Finally, there was no evidence to suggest that the tagged right whales occurred more frequently at higher climatological front probabilities (Fig. 4j), SST gradients (Fig. 4k), or surface chlorophyll gradients (Fig. $4 l$ ).

The results of the Monte Carlo tests for the bivariate frequency histogram of bottom temperature and bottom salinity
(Fig. 5a) suggest that particular bottom water properties were selected by the tagged right whales. Significantly more locations were found in the warmest and freshest waters, but all of these locations were from the single animal that visited Nantucket Shoals. Several of the bins found in cool and moderately fresh bottom waters had more locations and individuals than expected. In total, $30 \%$ of all locations outside the Bay of Fundy were found in bottom waters of less than $6{ }^{\circ} \mathrm{C}$ and $33.75 \mathrm{psu}\left(131, p_{\mathrm{U}}=0.0005\right)$ and more individuals were found in these bottom waters than expected $\left(9, p_{\mathrm{U}}=\right.$ 0.022 ). This bottom water mass was also characterized by low surface salinities, high surface stratification, and depths between 75 and $175 \mathrm{~m}$ (Fig. $5 \mathrm{~b}$ ). In contrast, bottom waters above $6{ }^{\circ} \mathrm{C}$ and lower than 33.75 psu were characterized by high surface salinities, low surface stratification, and shallower depths (between 25 and $150 \mathrm{~m}$ ). The deep basins had bottom waters above $6{ }^{\circ} \mathrm{C}$ and 33.75 psu and were characterized by greater depths and bimodal distributions of surface salinity and surface stratification. These bimodal distributions indicate the lower surface salinities and higher surface stratification over the deep basins of the Scotian Shelf (Emerald and La Have basins) and the high surface salinities and lower surface stratification over the deep basins of the Gulf of Maine (Wilkinson and Jordan basins and the Fundian Channel). Bottom waters below $6{ }^{\circ} \mathrm{C}$ and 33.75 psu occur in the western Gulf of Maine to the north and west of Wilkinson Basin, in the South Channel Ocean Productivity Experiment (SCOPEX) gyre, on the southwestern Scotian Shelf, and along the southern coast of Nova Scotia (Fig. 6). 
Fig. 3. Distribution of Argos-acquired locations outside the Bay of Fundy (shaded circles) and the results of one-tailed Monte Carlo tests of resource selection for the corresponding spatial-frequency histogram. Boxes indicate two-dimensional bins in which Monte Carlo tests were conducted. A significant number of locations and (or) individuals $\left(p_{\mathrm{U}}<0.05\right)$ were found in bins labeled with numbers. The label " 1 " indicates that only one individual occurred in the bin, but the number of locations was significantly higher than expected $\left(p_{U}<0.05\right)$. The observed number $(n)$ of locations or individuals and the mean number $(\mu)$ of locations or individuals in the sampling distribution for all other labeled bins are shown in the inset table $(*, 0.05>p \geq 0.01 ; * *, 0.01>p \geq 0.001 ; * * *, p<0.001)$. The 91-m (50 fathom) and 200-m isobaths are shown.

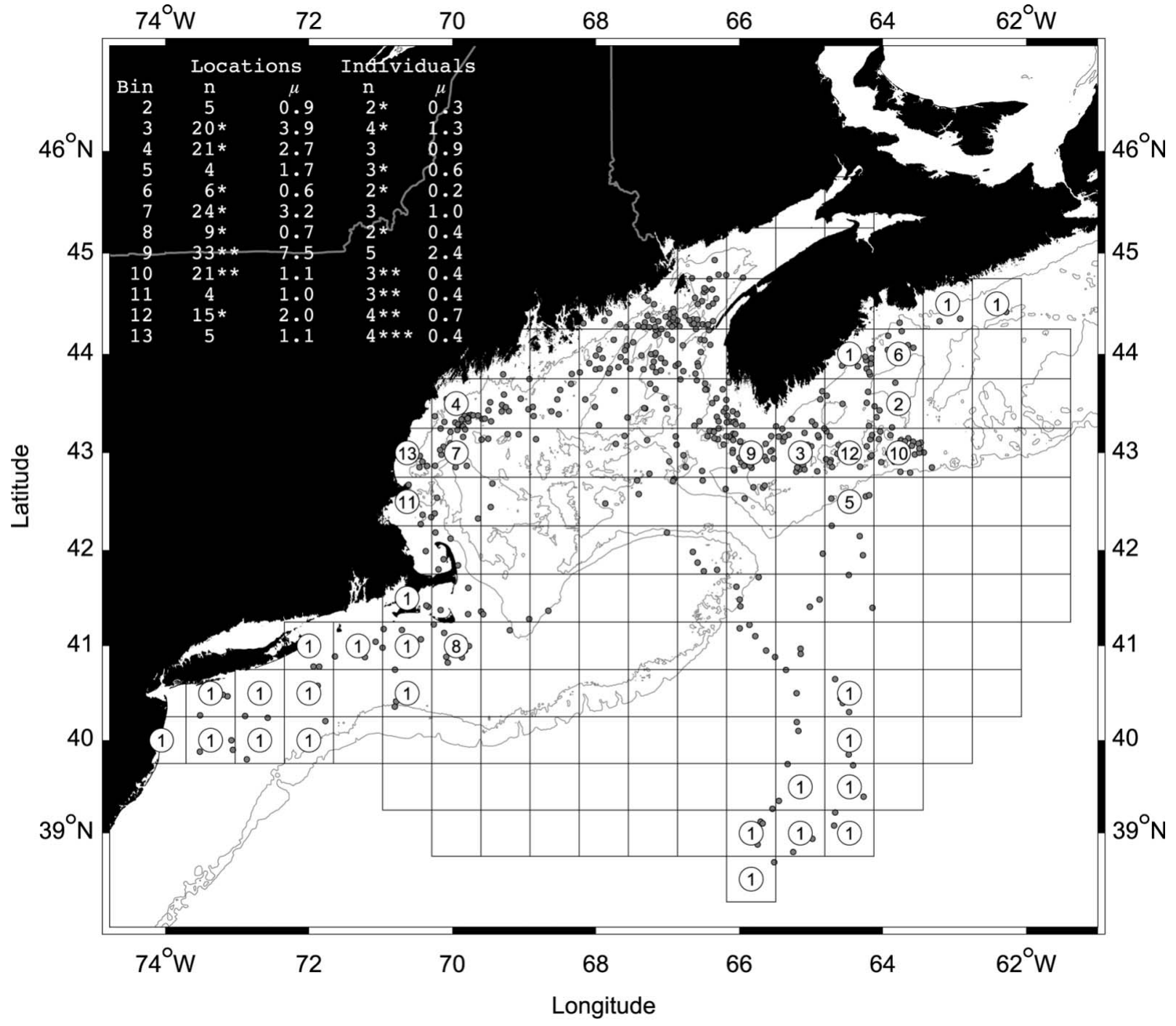

The areas that the tagged right whales visited more than expected (Fig. 3) correspond well to the spatial extent of these bottom waters.

\section{Discussion}

Upon exiting the lower Bay of Fundy, the tagged right whales moved extensively about the Gulf of Maine, Scotian Shelf, northern mid-Atlantic Bight, and the continental slope. Moving at an average speed of $79 \mathrm{~km} \cdot \mathrm{day}^{-1}$, right whales could circumnavigate the entire Gulf of Maine (including a visit to Roseway Basin) and return to the Bay of Fundy in only 15 days. Individual movements were highly variable and no other area or oceanographic regime was used as much as the lower Bay of Fundy. Of the 14 tagged animals that left the Bay of Fundy, 50\% returned to it before the tag stopped transmitting. Right whales have been observed during the summer and fall in some of the other areas frequently visited by the tagged animals, including the southwestern Scotian Shelf (Mitchell et al. 1986; Stone et al. 1988; CETAP 1982), the SCOPEX gyre (CETAP 1982), and the western Gulf of Maine (CETAP 1982; Payne et al. 1990; Weinrich et al. 2000).

The high site fidelity exhibited by tagged right whales in Grand Manan Basin in 2000 might suggest that food resources were abundant in that year compared with 19891991. In the summer and early fall of 1989, Woodley and Gaskin (1996) reported late-stage C. finmarchicus abundances of $1128 \pm 637$ copepods $\cdot \mathrm{m}^{-3}$ (mean \pm standard deviation) from 12 vertical tows near right whales in the basin. A single right whale was tagged in the same year and it left the Bay of Fundy soon after tagging and did not return during 
Table 5. Results of two-tailed Monte Carlo tests of the observed mean, standard deviation, skewness, and kurtosis ( $\theta$ ) of each environmental variable.

\begin{tabular}{|c|c|c|c|c|c|c|c|c|}
\hline & \multicolumn{2}{|l|}{ Mean } & \multicolumn{2}{|c|}{ Standard deviation } & \multicolumn{2}{|c|}{ Skewness } & \multicolumn{2}{|c|}{ Kurtosis } \\
\hline & $\theta$ & $\mu$ & $\theta$ & $\mu$ & $\theta$ & $\mu$ & $\theta$ & $\mu$ \\
\hline Depth (m) & 452.9 & 299.7 & 1099.1 & 632.6 & 3.27 & 5.73 & 9.32 & 44.14 \\
\hline Surface temperature $\left({ }^{\circ} \mathrm{C}\right)$ & 14.10 & 13.53 & 2.74 & 2.47 & 0.14 & 0.66 & -0.57 & 0.36 \\
\hline Surface salinity (psu) & $31.94 * *$ & 32.18 & 0.54 & 0.41 & 0.29 & 0.41 & 1.20 & 6.54 \\
\hline Bottom temperature $\left({ }^{\circ} \mathrm{C}\right)$ & $6.93^{*}$ & 7.56 & 2.09 & 1.56 & 1.74 & 0.84 & 6.31 & 3.52 \\
\hline Remotely sensed SST $\left({ }^{\circ} \mathrm{C}\right)^{a}$ & 14.43 & 13.48 & 3.33 & 2.40 & 0.71 & 0.89 & -0.10 & 1.51 \\
\hline Surface chlorophyll concn. $\left(\mathrm{mg} \cdot \mathrm{m}^{-3}\right)^{b}$ & 2.60 & 2.67 & 2.16 & 2.55 & 3.28 & 2.80 & 14.22 & 10.29 \\
\hline Front probability & 0.02 & 0.02 & 0.02 & 0.02 & 1.13 & 1.10 & 1.32 & 1.47 \\
\hline SST gradient $\left({ }^{\circ} \mathrm{C} \cdot \mathrm{km}^{-1}\right)^{a}$ & 0.14 & 0.14 & 0.06 & 0.06 & 1.10 & 1.68 & $0.51 *$ & 4.59 \\
\hline Chlorophyll gradient $\left(\mathrm{mg} \cdot \mathrm{m}^{-3} \cdot \mathrm{km}^{-1}\right)^{b}$ & 0.35 & 0.33 & 0.53 & 0.56 & 3.87 & 4.21 & 18.07 & 20.42 \\
\hline
\end{tabular}

Note: Results were obtained using only observed and simulated track segments outside the Bay of Fundy for all years. $\mu$ is the mean statistic from the sampling distribution. SST, sea-surface temperature; psu, practical salinity units. *, $0.05>p \geq 0.01 ; * *, 0.01>p \geq 0.001 ; * * *, p<0.001$.

a 1989-1991 data only.

${ }^{b} 2000$ data only.

the 21 days it was tracked. In 2000, Baumgartner et al. (2003a) observed late-stage C. finmarchicus abundances of only $457 \pm 74$ copepods $\cdot \mathrm{m}^{-3}$ in Grand Manan Basin from three oblique bongo tows near right whales on long dives (a typical characteristic of feeding activity in this area). These low abundances were corroborated with numerous independent optical plankton counter (Herman 1988, 1992) measurements (Baumgartner et al. 2003a). The C. finmarchicus abundances in 2000 represented a minimum in 3 years of zooplankton monitoring near right whales in Grand Manan Basin from 1999 to 2001 (Baumgartner et al. 2003a). Although extreme caution is warranted when attempting to characterize zooplankton abundance for an entire season with only a few plankton samples, the available data tenuously suggest that right whales remain in Grand Manan Basin for reasons other than feeding. Social and sexual activity is common in the Bay (Kraus and Hatch 2001), therefore it is possible that right whales remain in the Bay for breeding opportunities even when food resources are low.

There was no evidence to support the hypothesis that right whales used the deep basins of the Gulf of Maine and the Scotian Shelf (H1). Moreover, there was suggestive but inconclusive evidence that they actually avoided these basins. Sameoto and Herman (1990) and Herman et al. (1991) reported very high abundances of late-stage C. finmarchicus below $200 \mathrm{~m}$ in the basins of the Scotian Shelf (up to 20000 copepods $\cdot \mathrm{m}^{-3}$ ). Meise and O'Reilly (1996) demonstrated that the 10-year average total water column abundance of late-stage $C$. finmarchicus in the upper $200 \mathrm{~m}$ reaches a regional and annual maximum in the central Gulf of Maine in the summer and fall. Modeling results obtained by Lynch et al. (1998) suggest that high abundances of C. finmarchicus exist below $200 \mathrm{~m}$ in the Gulf of Maine basins. In light of these studies, it is somewhat surprising that right whales do not visit these basins more often. The basins have average depths of $210-250 \mathrm{~m}$, which is $40 \%-67 \%$ greater than the average depth in the Bay of Fundy or in Roseway Basin $(150 \mathrm{~m})$. It is plausible that the deepest portions of the basins are inaccessible to right whales; however, we have ob- served right whales tagged with time-depth recorders diving to depths of $200 \mathrm{~m}$ in Grand Manan Basin (Baumgartner and Mate 2003). Furthermore, the satellite-monitored radio tag deployed in 1989 was equipped with a pressure sensor, and the maximum dive depth for the single whale on which it was used was between 272 and $306 \mathrm{~m}$ in Wilkinson Basin. Based on these observations, we think it is unlikely that right whales have diving limitations that would prevent them from exploiting $C$. finmarchicus concentrations below $200 \mathrm{~m}$. Although right whales may be physiologically capable of reaching discrete layers of C. finmarchicus at these depths, they may still avoid foraging on these layers. Foraging at deeper depths affords less feeding time, and thus less energetic benefit per dive, than foraging at shallower depths (Baumgartner et al. 2003a).

Prey concentrations that are ecologically meaningful to right whales are difficult to measure at depth with plankton nets. The vertically integrated tows upon which the Meise and O'Reilly (1996) climatology is based can only provide an average water-column abundance of $C$. finmarchicus. This average abundance grossly underestimates the concentration of prey actually available to a right whale because the whales seek out and feed on prey that are distributed vertically in discrete layers (Baumgartner and Mate 2003). So despite the high total water-column abundances present in the Gulf of Maine basins, our results suggest that discrete, high concentrations of late-stage $C$. finmarchicus may not exist there. This is in contrast to the prediction of Lynch et al. (1998) that high concentrations of resting $C$. finmarchicus must exist below $200 \mathrm{~m}$ in these basins during the fall to explain the springtime distribution of younger stages of C. finmarchicus. We sampled Jordan and Wilkinson basins in the summer of 2001 with a vertically profiled optical plankton counter and did not observe any discrete, high concentration layers of $C$. finmarchicus below $200 \mathrm{~m}$ (M.F. Baumgartner, unpublished data). These layers were, however, readily observable at mid-depth near foraging right whales in Grand Manan Basin with the same instrument (Baumgartner and Mate 2003). The high concentrations ob- 


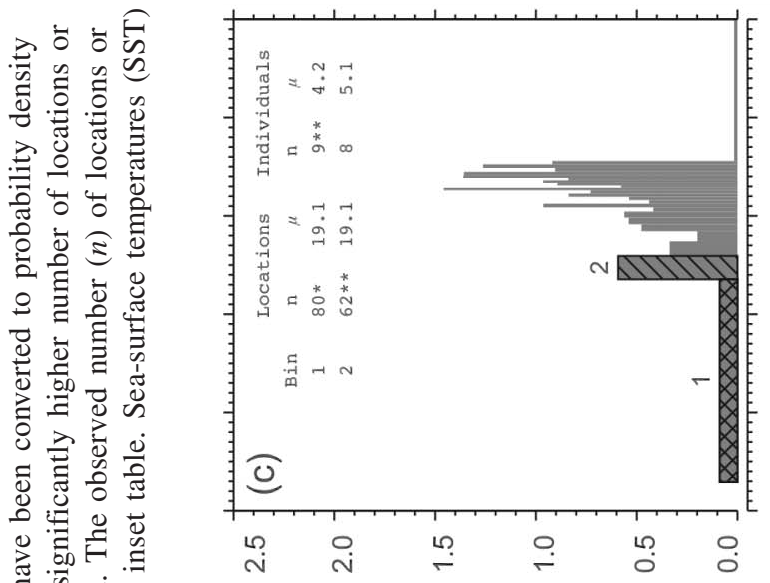

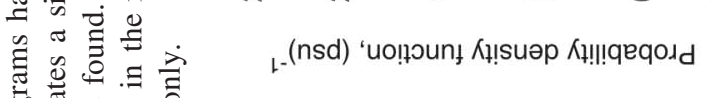

कृ :

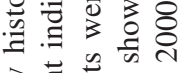

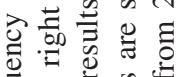

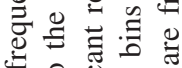

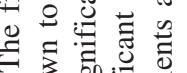

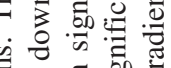

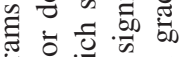

क율

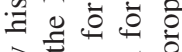

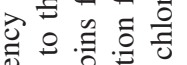

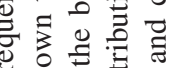

o b o : क :

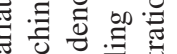

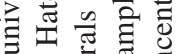

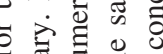

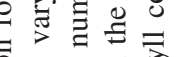

రิ

论

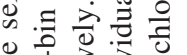

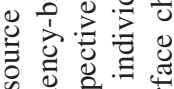

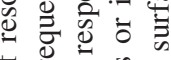

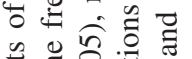

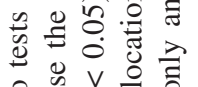

을

ป 3

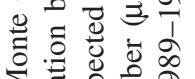

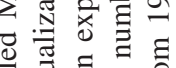

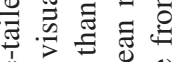

$\stackrel{\Xi}{\Xi} \Xi$

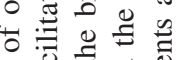

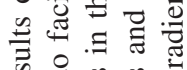

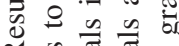

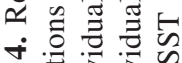

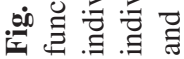

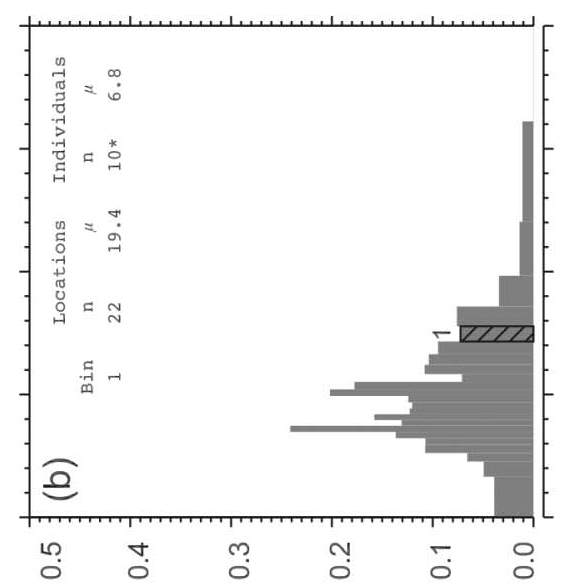

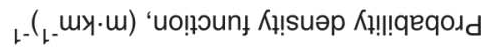

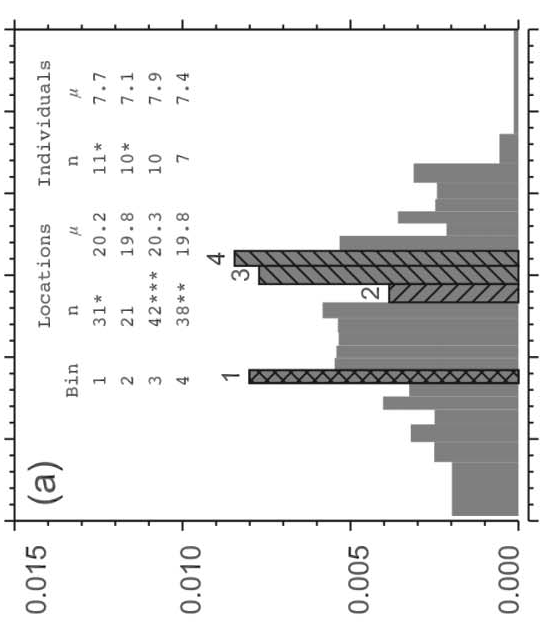

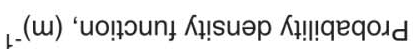

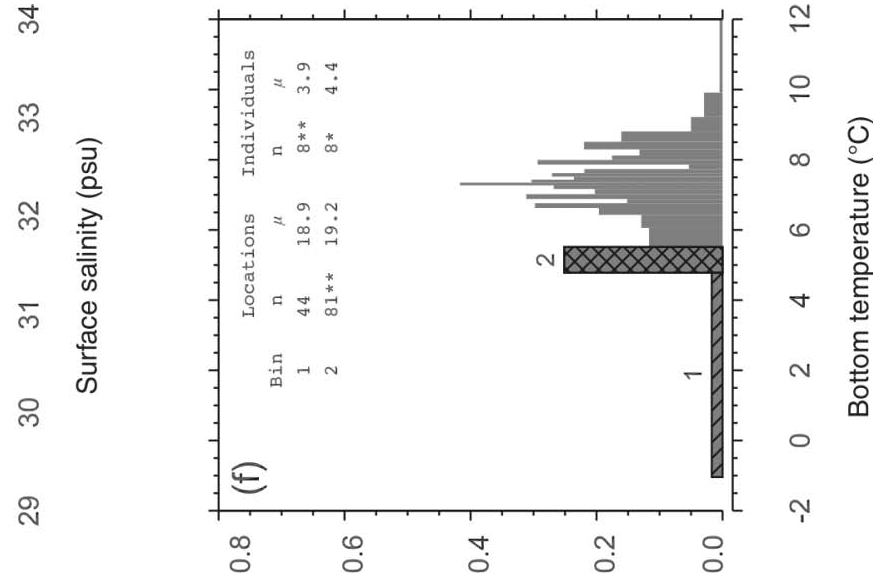

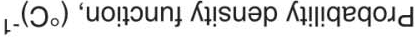

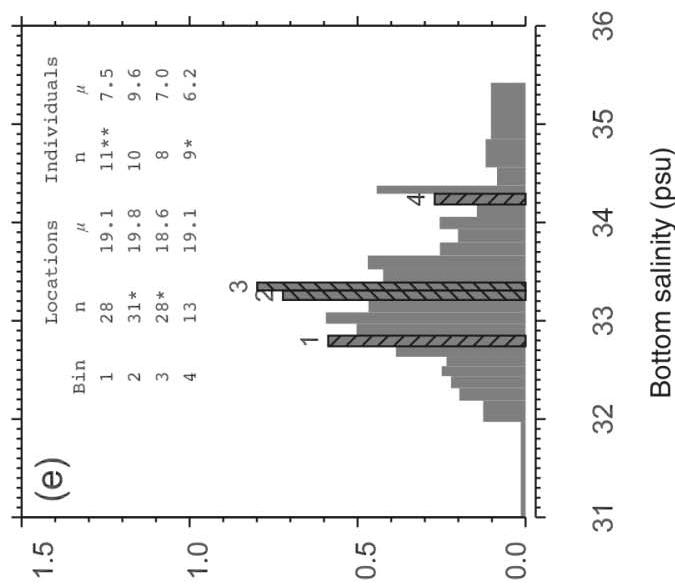

L-(nsd) 'uo!!̣ounł Kł!suəp Kł!!!qeqodd

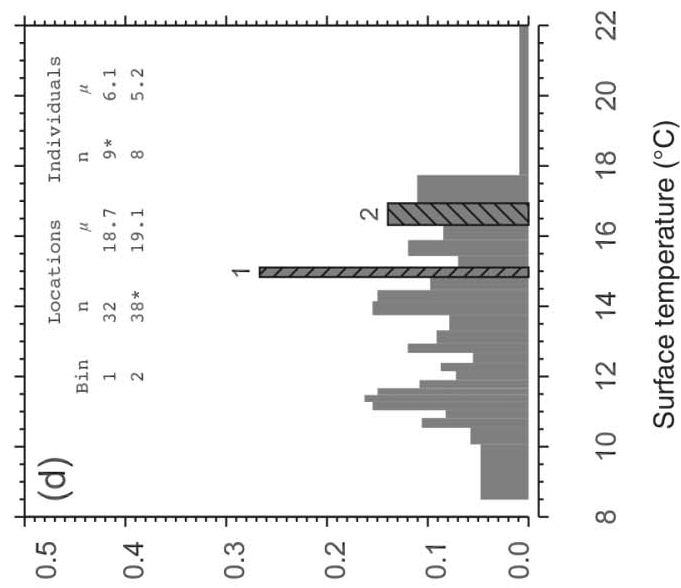

Ł-(つ.) ‘uo!̣ounı Kł!suəp Kł!!!qeqodd 


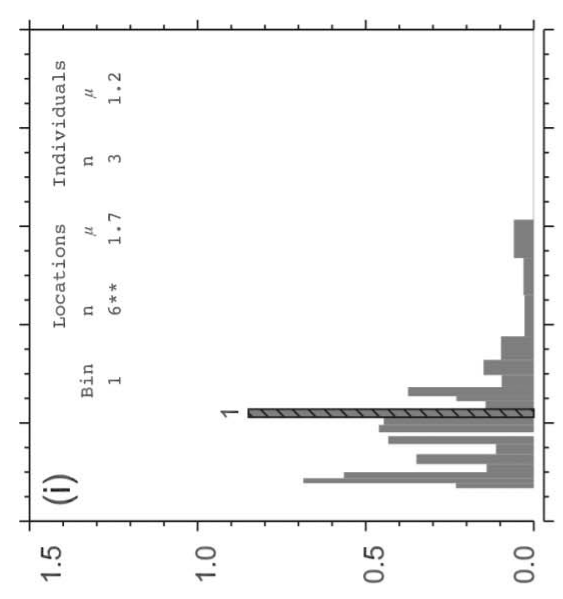

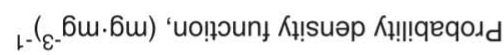

으

$\infty$

$\omega$

(1)

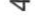

N

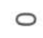

○

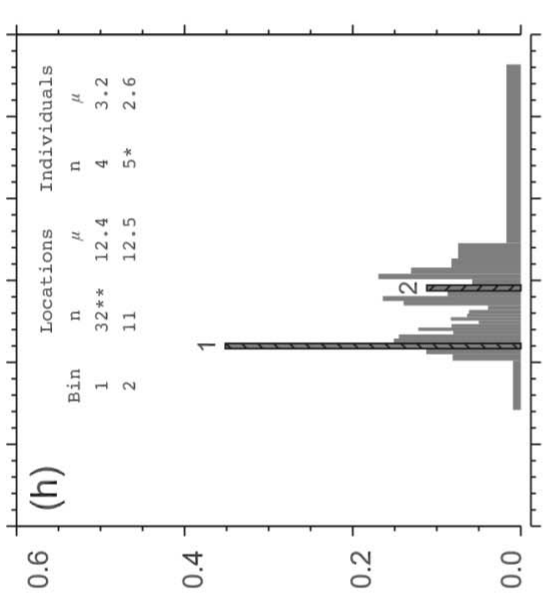

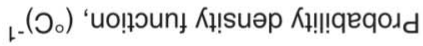
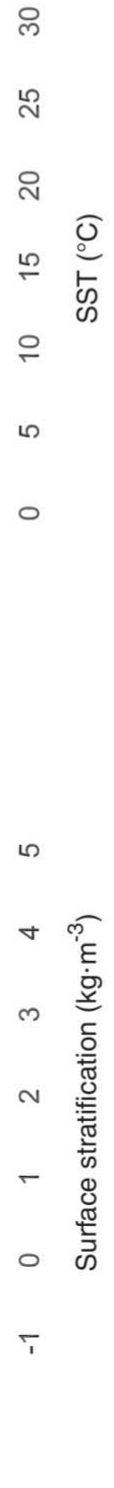

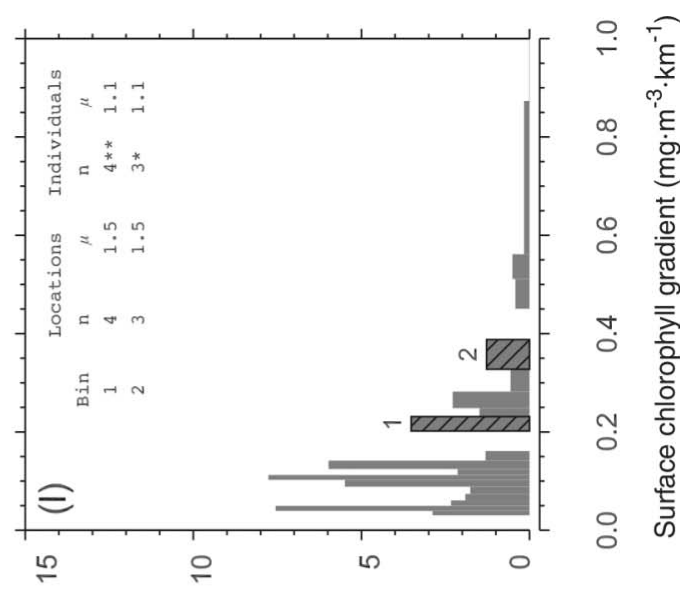

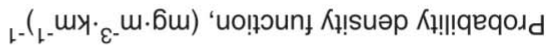

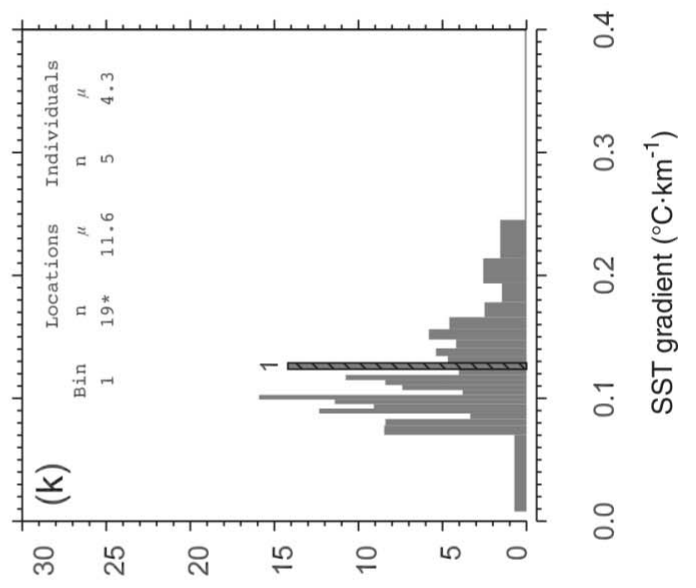

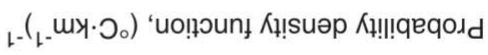

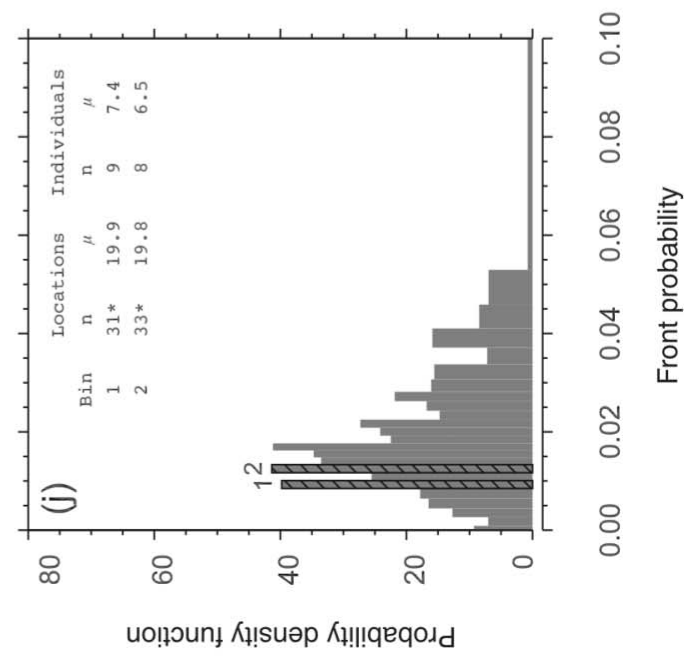


Fig. 5. (a) Distribution of bottom salinity and temperature at Argos-acquired locations (shaded circles) and results of one-tailed Monte Carlo tests of resource selection for the corresponding bivariate frequency histogram. Boxes indicate two-dimensional bins in which Monte Carlo tests were conducted. Numerals denote bins in which a significant number of locations and (or) individuals $\left(p_{\mathrm{U}}<0.05\right.$ ) were found. The label "1" indicates that only one individual occurred in the bin, but the number of locations was significantly higher than expected $\left(p_{\mathrm{U}}<0.05\right)$. The observed number $(n)$ of locations or individuals and the mean number $(\mu)$ of locations or individuals in the sampling distribution for all other labeled bins are shown in the inset table. (b) Distribution of bottom salinity and temperature at the same locations as in $a$ with percent-frequency histograms of surface salinity (SSAL), surface stratification (STRAT), and depth (DEP) for locations in quadrants defined by bottom temperature (BT) $<6{ }^{\circ} \mathrm{C}$ and bottom salinity (BS) $<33.75$ practical salinity units (psu) (lower left), $\mathrm{BT} \geq 6{ }^{\circ} \mathrm{C}$ and $\mathrm{BS}<33.75 \mathrm{psu}$ (upper left), and $\mathrm{BT} \geq 6{ }^{\circ} \mathrm{C}$ and $\mathrm{BS} \geq 33.75$ psu (upper right).

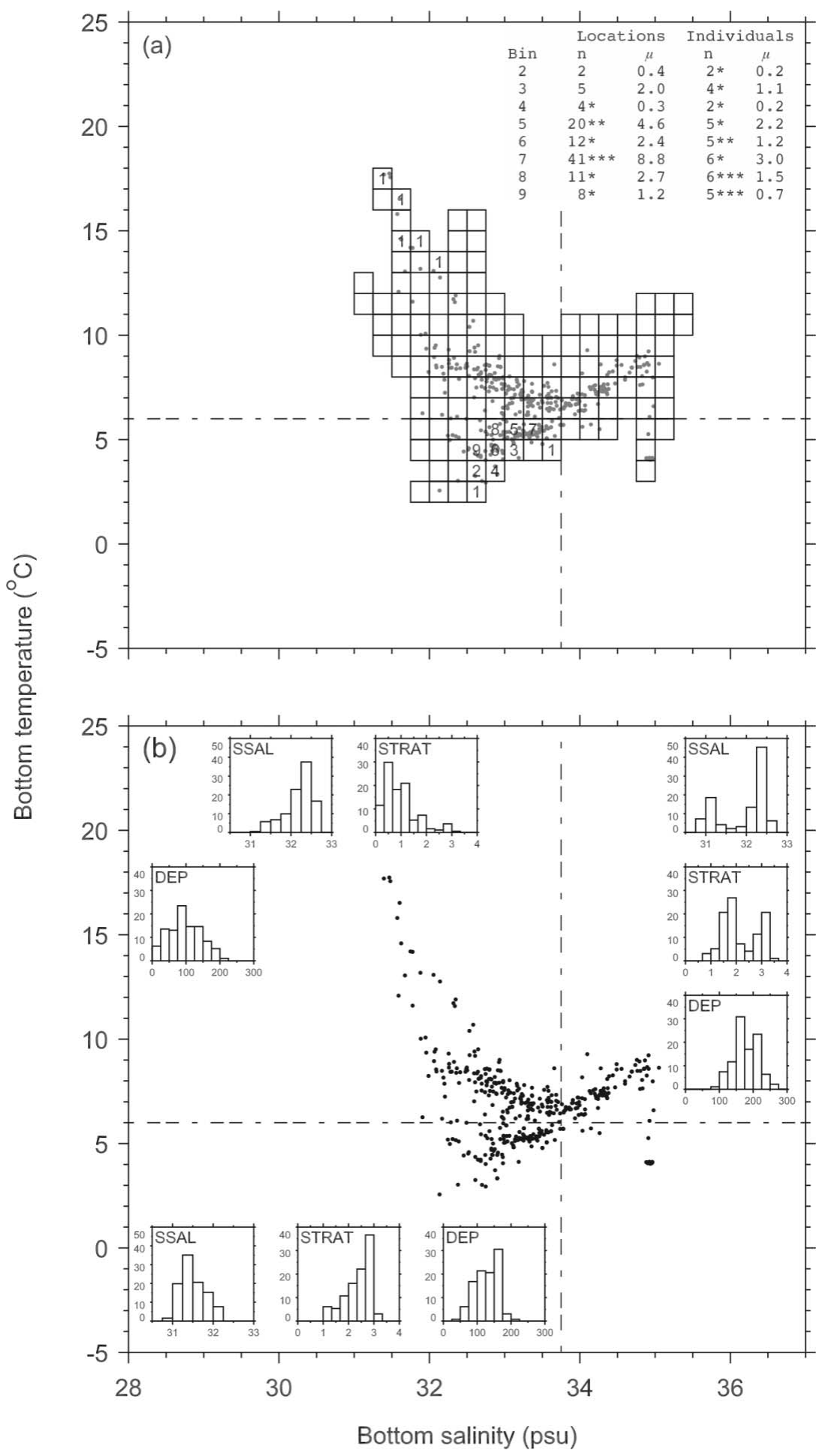


Fig. 6. Map of areas with bottom temperature less than $6{ }^{\circ} \mathrm{C}$ and bottom salinity less than 33.75 psu (cross-hatched). Shaded circles indicate Argos-acquired locations outside the Bay of Fundy. The 91-m (50 fathom) and 200-m isobaths are also shown.

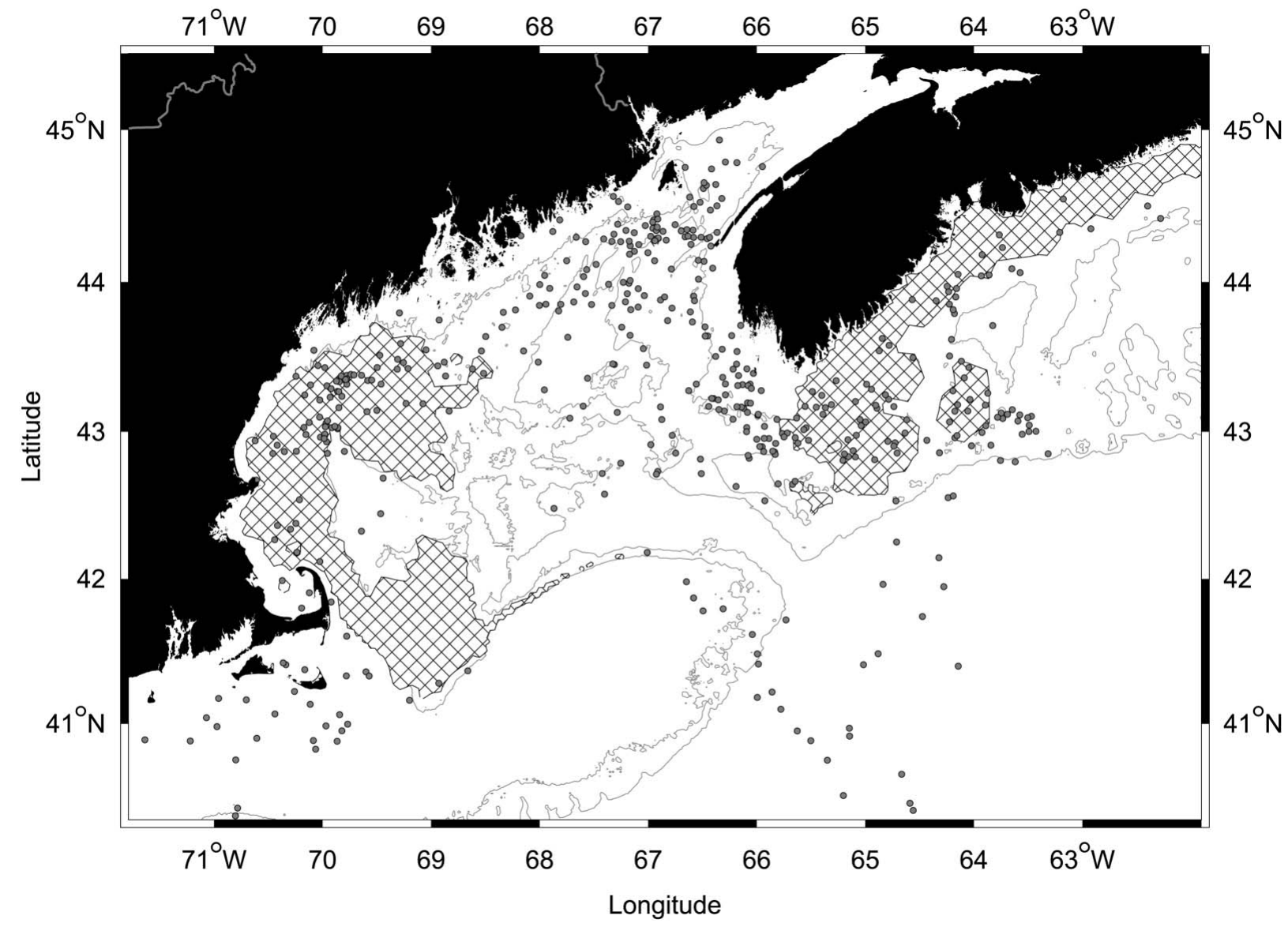

served by Sameoto and Herman (1990) and Herman et al. (1991) in the deep basins of the Scotian Shelf would certainly be attractive to right whales, but the paucity of Argos locations acquired there suggests that these concentrations may not be present every year.

There was no evidence to support the hypothesis that right whales associate with oceanic fronts or visit areas that are climatologically rich in fronts (H2). Despite the presence of a strong tidal mixing front along the western margin of Grand Manan Basin, Murison and Gaskin (1989) and Woodley and Gaskin (1996) found that right whales occupied the central basin, well away from this front. Brown and Winn (1989) observed that right whales were nearly always on the stratified side of a persistent tidal mixing front in the Great South Channel during the spring, but were a median $11.4 \mathrm{~km}$ away from it. Wishner et al. (1995) found dense concentrations of $C$. finmarchicus at the leading edge of a low-salinity plume during the 2 years of the SCOPEX study in the Great South Channel (Kenney and Wishner 1995), but Beardsley et al. (1996) found no evidence of a physical concentrating mechanism near a right whale feeding on very large aggregations of $C$. finmarchicus during that study. Baumgartner et al. (2003a) found no evidence of an association between right whale occurrence and oceanic fronts in the lower Bay of Fundy, but they did find evidence of such an association in Roseway Basin. While it is possible that fronts may ag- gregate prey in particular regions, our results suggest that oceanic fronts are not a common feature of right whale habitat.

There was no evidence to support the hypothesis that right whales frequent areas with high surface chlorophyll concentrations (H3). This is not particularly surprising when considered in the context of $C$. finmarchicus life history. When C. finmarchicus reach stage C5, they typically undertake an ontogenetic vertical migration to depth, where they enter a resting state (termed diapause) (Hirche 1996). Calanus finmarchicus C5 do not feed during diapause, relying on their considerable lipid reserves to support metabolism (although see Durbin et al. 1995). Female C. finmarchicus spawn the year's first generation (G1) of copepods in midwinter, which matures in early spring (Durbin et al. 1997, 2000). While some $C$. finmarchicus C5 enter diapause at this time, others remain at the surface to become the progenitors of the next generation of copepods (G2). The G2 generation reaches stage 4 or 5 by late spring or early summer. Some G2 animals may remain at the surface to spawn a third generation (G3), but the bulk of the C. finmarchicus population can be found at depth as C5 by summer. Baumgartner and Mate (2003) observed right whales foraging on deep layers of C. finmarchicus C5 in the lower Bay of Fundy and Roseway Basin during the summer. Moreover, diel vertical migration studies of $C$. finmarchicus in the lower Bay of Fundy carried out at that time indicate that the animals in 
these layers have empty guts and do not migrate to the surface (Baumgartner et al. 2003b). Since phytoplankton abundance is irrelevant to nonfeeding $C$. finmarchicus C5 in diapause during the summer and early fall, right whale distribution is accordingly unrelated to surface chlorophyll concentration.

The tagged right whales' preference for waters with low bottom temperatures suggests that these conditions may improve feeding opportunities by promoting higher $C$. finmarchicus abundance or better quality food. Oceanic populations of $C$. finmarchicus typically migrate to several hundred metres depth (Miller et al. 1991), where the ambient temperature is typically only a few degrees Celsius. Continentalshelf populations, however, do not have access to such great depths and low temperatures. The lipid reserves upon which C. finmarchicus rely to survive starvation during diapause are depleted faster at higher temperatures because metabolic rates in resting stocks increase with temperature (Hirche 1983). The lower bottom temperatures found in the areas visited by the tagged right whales, therefore, may promote higher abundances by improving $C$. finmarchicus survivorship relative to the warmer bottom waters of the deep basins or the coastal environment. Meise and O'Reilly (1996) demonstrated that average water-column abundance of late-stage C. finmarchicus was negatively correlated with average water-column temperature in the summer and fall, suggesting that, indeed, lower temperatures improve survivorship of resting stocks. Sameoto and Herman (1990) reported a large decrease in Emerald Basin Calanus spp. over the winter and they raised the possibility (among others) that copepods could not survive diapause in the $8.5-10{ }^{\circ} \mathrm{C}$ waters at depth. For copepods that migrate to depth at the same time in the early summer, lipid reserves (and therefore energetic content) will be higher during the summer and fall in those animals that descend to colder waters. Therefore, right whales foraging in waters with lower bottom temperatures may also encounter higher quality food relative to what is available in waters with higher bottom temperatures.

The tagged whales visited areas with depths of roughly $150 \mathrm{~m}$ more frequently than expected. These areas can be characterized as shallow basins. The structure, hydrography, and physical processes of these basins may improve the availability, quality, and aggregation of C. finmarchicus, respectively, for foraging right whales. Shoal layers of prey allow longer feeding times for right whales relative to deeper layers and thus are more energetically favorable (Baumgartner et al. 2003a). In contrast to deeper basins, the shoal depths of shallow basins guarantee shoal layers of prey. While the bottom waters of deeper basins are warm because of slope water intrusions, lower temperatures prevail near the bottom of shallow basins. As discussed above, these conditions may improve survivorship and reduce oil depletion in resting C. finmarchicus, so prey abundance and quality may be enhanced in shallow basins. Strong tidal currents in the Gulf of Maine and Scotian Shelf act on the sea floor to generate turbulence and a well-mixed bottom layer. Baumgartner and Mate (2003) consistently found C. finmarchicus C5 in discrete layers just above this bottom mixed layer near feeding right whales in the lower Bay of Fundy and Roseway Basin. Unlike in very shallow regions, where the surface and bot- tom mixed layers interact and copepods may become uniformly distributed (e.g., Georges Bank, Nantucket Shoals), resting stocks of $C$. finmarchicus in shallow basins may be vertically aggregated between surface and bottom mixed layers. The tide also produces cyclonic circulation over shallow basins via tidal rectification, which, if sufficiently strong, may horizontally aggregate and retain $C$. finmarchicus as well. Tidal rectification generates a cyclonic gyre over Grand Manan Basin (Lynch et al. 1996) in which Woodley and Gaskin (1996) and Baumgartner et al. (2003a) suggest that late-stage $C$. finmarchicus are aggregated and made available to foraging right whales.

The spatial and temporal scales of the present study (hundreds of kilometres, tens of days) would be impossible to study using ship-based or aerial surveys. Even if these methods were viable, the rarity of right whale sightings over these spatial scales would make habitat analyses futile. Radio tracking provides direct observations of resource selection and is therefore a useful tool for studying right whale habitat at these larger spatial scales. Considering the large volume of tracking data for marine vertebrates collected to date, improving the statistical methods to analyze satelliteacquired locations and associated environmental data is a particularly fruitful avenue of research. With approaches such as those presented here, much can be learned about marine habitats with data already in hand.

\section{Acknowledgments}

We are grateful for assistance in the field by P. Duley, S. Kraus, B. Lagerquist, T. Martin, M.L. Mate, S. Nieukirk, J. Owen, D. Stahlke, F. Wenzel, and the New England Aquarium right whale group. We also received critical support from the chief scientists, Phil Clapham and Tim Cole, and the master, officers, and crew of the National Oceanic and Atmospheric Administration (NOAA) ship Delaware II. We thank R. Mesecar for tag design and development, T. Martin and T. Follett for technical support, and the New England Aquarium for identifying the tagged whales. P. Cornillon and R. Evans provided access to the University of Rhode Island's advanced very high resolution radiometer archive. We are particluarly grateful to J. Loder and D. Ullman for providing access to their respective hydrographic and frontprobability climatologies. This study was supported by the Office of Naval Research, National Marine Fisheries Service, Oregon State University Marine Mammal Endowment, and the Space Grant and Earth System Science fellowship programs of the National Aeronautics and Space Administration.

\section{References}

Baith, K., Lindsay, R., Fu, G., and McClain, C.R. 2001. SeaDAS: data analysis system developed for ocean color satellite sensors. EOS Trans. Am. Geophys. Union, 82: 202-205.

Baumgartner, M.F., and Mate, B.R. 2003. Summertime foraging ecology of North Atlantic right whales. Mar. Ecol. Prog. Ser. 264: 123-135.

Baumgartner, M.F., Mullin, K.D., May, L.N., and Leming, T.D. 2001. Cetacean habitats in the northern Gulf of Mexico. Fish. Bull. 99: 219-239. 
Baumgartner, M.F., Cole, T.V.N., Clapham, P.J., and Mate, B.R. $2003 a$. North Atlantic right whale habitat in the lower Bay of Fundy and on the SW Scotian Shelf during 1999-2001. Mar. Ecol. Prog. Ser. 264:137-154.

Baumgartner, M.F., Cole, T.V.N., Campbell, R.G., Teegarden, G.J., and Durbin, E.G. 2003b. Associations between North Atlantic right whales and their prey, Calanus finmarchicus, over diel and tidal time scales. Mar. Ecol. Prog. Ser. 264:155-166.

Beardsley, R.C., Epstein, A.W., Chen, C., Wishner, K.F., Macaulay, M.C., and Kenney, R.D. 1996. Spatial variability in zooplankton abundance near feeding right whales in the Great South Channel. Deep-Sea Res. II, 43: 1601-1625.

Brown, C.W., and Winn, H.E. 1989. Relationship between the distribution pattern of right whales, Eubalaena glacialis, and satellite-derived sea surface thermal structure in the Great South Channel. Cont. Shelf Res. 9: 247-260.

Caswell, H., Fujiwara, M., and Brault, S. 1999. Declining survival probability threatens the North Atlantic right whale. Proc. Natl. Acad. Sci. U.S.A. 96: 3308-3313.

Cetacean and Turtle Assessment Program. 1982. A characterization of marine mammals and turtles in the mid- and north Atlantic areas of the U.S. outer continental shelf. Final report, Bureau of Land Management, Washington, D.C., USA. (Rep. No. PB83215855, National Technical Information Service, Springfield, VA 22161, USA.)

Clapham, P.J., Young, S.B., and Brownell, R.L., Jr. 1999. Baleen whales: conservation issues and the status of the most endangered populations. Mamm. Rev. 29: 35-60.

Cornillon P., Gilman, C., Stramma, L., Brown, O., Evans, R., and Brown, J. 1987. Processing and analysis of large volumes of satellite-derived thermal infrared data. J. Geophys. Res. 92: 12993 -13002 .

Durbin, E.G., Campbell, R.G., Gilman, S.L., and Durbin, A.G. 1995. Diel feeding behavior and ingestion rate in the copepod Calanus finmarchicus in the southern Gulf of Maine during the late spring. Cont. Shelf Res. 15: 539-570.

Durbin, E.G., Runge, J.A., Campbell, R.G., Garrahan, P.R., Casas, M.C., and Plourde, S. 1997. Late fall - early winter recruitment of Calanus finmarchicus on Georges Bank. Mar. Ecol. Prog. Ser. 151: 103-114.

Durbin, E.G., Garrahan, P.R., and Casas, M.C. 2000. Abundance and distribution of Calanus finmarchicus on the Georges Bank during 1995 and 1996. ICES J. Mar. Sci. 57: 1664-1685.

Epstein, A.W., and Beardsley, R.C. 2001. Flow-induced aggregation of plankton at a front: a 2-D Eulerian model study. DeepSea Res. II, 48: 395-418.

Herman, A.W. 1988. Simultaneous measurement of zooplankton and light attenuance with a new optical plankton counter. Cont. Shelf Res. 8: 205-221.

Herman, A.W. 1992. Design and calibration of a new optical plankton counter capable of sizing small zooplankton. Deep-Sea Res. 39: 395-415.

Herman, A.W., Sameoto, D.D., Shunnian, C., Mitchell, M.R., Petrie, B., and Cochrane, N. 1991. Sources of zooplankton on the Nova Scotia Shelf and their aggregations within deep-shelf basins. Cont. Shelf Res. 11: 211-238.

Hirche, H.-J. 1983. Overwintering Calanus finmarchicus and Calanus helgolandicus. Mar. Ecol. Prog. Ser. 11: 281-290.

Hirche, H-.J. 1996. Diapause in the marine copepod, Calanus finmarchicus - a review. Ophelia, 44: 129-143.

International Whaling Commission. 2001. Report of the workshop on status and trends of western North Atlantic right whales. J. Cetacean Res. Manag. Spec. Issue No. 2. pp. 61-87.
Kenney, R.D., and Winn, H.E. 1986. Cetacean high-use habitats of the northeast United States continental shelf. Fish. Bull. 84: 345-357.

Kenney, R.D., and Wishner, K.F. 1995. The South Channel ocean productivity experiment. Cont. Shelf Res. 15: 373-384.

Kenney, R.D., Hyman, M.A.M., Owen, R.E., Scott, G.P., and Winn, H.E. 1986. Estimation of prey densities required by western North Atlantic right whales. Mar. Mamm. Sci. 2: 1-13.

Knowlton, A.R., and Kraus, S.D. 2001. Mortality and serious injury of northern right whales (Eubalaena glacialis) in the western North Atlantic Ocean. J. Cetacean Res. Manag. Spec. Issue No. 2. pp. 193-208.

Kraus, S.D. 1990. Rates and potential causes of mortality in North Atlantic right whales (Eubalaena glacialis). Mar. Mamm. Sci. 6: 278-291.

Kraus, S.D., and Hatch, J.J. 2001. Mating strategies in the North Atlantic right whale (Eubalaena glacialis). J. Cetacean Res. Manag. Spec. Issue No. 2. pp. 237-244.

Kraus, S.D., Moore, K.E., Price, C.A., Crone, M.J., Watkins, W.A., Winn, H.E., and Prescott, J.H. 1986. The use of photographs to identify individual North Atlantic right whales (Eubalaena glacialis). Rep. Int. Whaling Comm. Spec. Issue No. 10. pp. $145-151$.

Loder, J.W., Han, G., Hannah, C.G., Greenberg, D.A., and Smith, P.C. 1997. Hydrography and baroclinic circulation in the Scotian Shelf region: winter versus summer. Can. J. Fish. Aquat. Sci. 54: $40-56$.

Lynch, D.R., Ip, J.T.C., Naimie, C.E., and Werner, F.E. 1996. Comprehensive coastal circulation model with application to the Gulf of Maine. Cont. Shelf Res. 16: 875-906.

Lynch, D.R., Gentleman, W.C., McGillicuddy, D.J., Jr., and Davis, C.S. 1998. Biological/physical simulations of Calanus finmarchicus population dynamics in the Gulf of Maine. Mar. Ecol. Prog. Ser. 169: 189-210.

Manly, B.F.J. 1997. Randomization, bootstrap and Monte Carlo methods in biology. Chapman \& Hall, London.

Mate, B.R., Nieukirk, S.L., and Kraus, S.D. 1997. Satellitemonitored movements of the northern right whale. J. Wildl. Manag. 61: 1393-1405.

Mate, B.R., Gisiner, R., and Mobley, J. 1998. Local and migratory movements of Hawaiian humpback whales tracked by satellite telemetry. Can. J. Zool. 76: 863-868.

Mate, B.R., Lagerquist, B.A., and Calambokidis, J. 1999. The movements of North Pacific blue whales off southern California and their southern fall migration. Mar. Mamm. Sci. 15: 12461257.

Mayo, C.A., and Marx, M.K. 1990. Surface foraging behavior of the North Atlantic right whale, Eubalaena glacialis, and associated zooplankton characteristics. Can. J. Zool. 68: 2214-2220.

Meise, C.J., and O'Reilly, J.E. 1996. Spatial and seasonal patterns in abundance and age-composition of Calanus finmarchicus in the Gulf of Maine and on Georges Bank: 1977-1987. Deep-Sea Res. II, 43: 1473-1501

Miller, C.B., Cowles, T.J., Wiebe, P.H., Copley, N.C., and Grigg, H. 1991. Phenology in Calanus finmarchicus: hypotheses about control mechanisms. Mar. Ecol. Prog. Ser. 72: 79-91.

Mitchell, E., Kozicki, V.M., and Reeves, R.R. 1986. Sightings of right whales, Eubalaena glacialis, on the Scotian Shelf, 19661972. Rep. Int. Whaling Comm. Spec. Issue No. 10. pp. 83-107.

Mountain, D.G., and Jessen, P.F. 1987. Bottom waters of the Gulf of Maine, 1978-1983. J. Mar. Res. 45: 319-345.

Murison, L.D., and Gaskin, G.E. 1989. The distribution of right whales and zooplankton in the Bay of Fundy, Canada. Can. J. Zool. 67: 1411-1420. 
National Geophysical Data Center. 1988. Digital relief of the surface of the Earth. National Oceanic and Atmospheric Administration Data Announcement 88-MGG-02, Boulder, Color. Available from http://www.ngdc.noaa.gov/mgg/global/etopo5.html [accessed 3 April 2000; updated 27 December 2004].

Olson, D.B., and Backus, R.H. 1985. The concentrating of organisms at fronts: a cold-water fish and a warm-core Gulf Stream ring. J. Mar. Res. 43: 113-137.

Payne, P.M., Wiley, D.N., Young, S.B., Pittman, S., Clapham, P.J., and Jossi, J.W. 1990. Recent fluctuations in the abundance of baleen whales in the southern Gulf of Maine in relation to changes in selected prey. Fish. Bull. 88: 687-696.

Reilly, S.B. 1990. Seasonal changes in distribution and habitat differences among dolphins in the eastern tropical Pacific. Mar. Ecol. Prog. Ser. 66: 1-11.

Russ, J.C. 1995. The image processing handbook. 2nd ed. CRC Press, Boca Raton, Fla.

Sameoto, D.D., and Herman, A.W. 1990. Life cycle and distribution of Calanus finmarchicus in deep basins on the Nova Scotia shelf and seasonal changes in Calanus spp. Mar. Ecol. Prog. Ser. 66: $225-237$.

Smith, W.H.F., and Sandwell, D.T. 1997. Global seafloor topography from satellite altimetry and ship depth soundings. Science (Wash., D.C.), 277: 1957-1962.
Stone, G.S., Kraus, S.D., Prescott, J.H., and Hazard, K.W. 1988. Significant aggregations of the endangered right whale, Eubalaena glacialis, on the continental shelf of Nova Scotia. Can. Field-Nat. 102: 471-474.

Ullman, D.S., and Cornillon, P.C. 1999. Satellite derived sea surface temperature fronts on the continental shelf off the northeast U.S. coast. J. Geophys. Res. 104: 23459 - 23478.

Watkins, W.A., and Schevill, W.E. 1976. Right whale feeding and baleen rattle. J. Mammal. 57: 58-66.

Weinrich, M.T., Kenney, R.D., and Hamilton, P.K. 2000. Right whales (Eubalaena glacialis) on Jeffreys Ledge: a habitat of unrecognized importance? Mar. Mamm. Sci. 16: 326-337.

Wishner, K., Durbin, E., Durbin, A., Macaulay, M., Winn, H., and Kenney, R. 1988. Copepod patches and right whales in the Great South Channel off New England. Bull. Mar. Sci. 43: 825-844.

Wishner, K.F., Schoenherr, J.R., Beardsley, R., and Chen, C. 1995. Abundance, distribution and population structure of the copepod Calanus finmarchicus in a springtime right whale feeding area in the southwestern Gulf of Maine. Cont. Shelf Res. 15: 475507.

Woodley, T.H., and Gaskin, D.E. 1996. Environmental characteristics of North Atlantic right and fin whale habitat in the lower Bay of Fundy, Canada. Can. J. Zool. 74: 75-84. 